\title{
Proteomics Analysis of E. angustifolia Seedlings Inoculated with Arbuscular Mycorrhizal Fungi under Salt Stress
}

\author{
Tingting Jia ${ }^{1,2}$, Jian Wang ${ }^{1,2}$, Wei Chang ${ }^{1,2}$, Xiaoxu Fan ${ }^{1,2}$, Xin Sui ${ }^{1,2}$ and Fuqiang Song $1,2, *$ (i) \\ 1 Engineering Research Center of Agricultural Microbiology Technology, Ministry of Education, \\ Heilongiiang University, Harbin 150500, China; 18945081056@163.com (T.J.); 13796672755@163.com (J.W.); \\ changwei77@126.com (W.C.); fan_xiao_xu@126.com (X.F.); xinsui_cool@126.com (X.S.) \\ 2 Heilongiiang Provincial Key Laboratory of Ecological Restoration and Resource Utilization for Cold Region, \\ School of Life Sciences, Heilongjiang University, Harbin 150080, China \\ * Correspondence: 0431sfq@163.com
}

Received: 7 December 2018; Accepted: 1 February 2019; Published: 12 February 2019

\begin{abstract}
To reveal the mechanism of salinity stress alleviation by arbuscular mycorrhizal fungi (AMF), we investigated the growth parameter, soluble sugar, soluble protein, and protein abundance pattern of E. angustifolia seedlings that were cultured under salinity stress $(300 \mathrm{mmol} / \mathrm{L} \mathrm{NaCl})$ and inoculated by Rhizophagus irregularis (RI). Furthermore, a label-free quantitative proteomics approach was used to reveal the stress-responsive proteins in the leaves of E. angustifolia. The result indicates that the abundance of 75 proteins in the leaves was significantly influenced when E. angustifolia was inoculated with AMF, which were mainly involved in the metabolism, signal transduction, and reactive oxygen species (ROS) scavenging. Furthermore, we identified chorismate mutase, elongation factor mitochondrial, peptidyl-prolyl cis-trans isomerase, calcium-dependent kinase, glutathione S-transferase, glutathione peroxidase, NADH dehydrogenase, alkaline neutral invertase, peroxidase, and other proteins closely related to the salt tolerance process. The proteomic results indicated that E. angustifolia seedlings inoculated with AMF increased the secondary metabolism level of phenylpropane metabolism, enhanced the signal transduction of $\mathrm{Ca}^{2+}$ and ROS scavenging ability, promoted the biosynthesis of protein, accelerated the protein folding, and inhibited the degradation of protein under salt stress. Moreover, AMF enhanced the synthesis of ATP and provided sufficient energy for plant cell activity. This study implied that symbiosis of halophytes and AMF has potential as an application for the improvement of saline-alkali soils.
\end{abstract}

Keywords: arbuscular mycorrhizal fungi; salt stress; E. angustifolia; proteomics

\section{Introduction}

Salt stress is one of the most important abiotic stresses and limiting factors for plant growth and agricultural production. It is a major abiotic stress in the world. Land salinization causes many ecological and environmental problems, such as soil erosion, land desertification, forest and grassland degradation, and biodiversity reduction [1]. At present, along with the increase in soil salinization and secondary salinization, it is estimated that $30 \%$ of the arable land in the world will disappear in the next 25 years, and $50 \%$ by the middle of the 21 st century [2,3]. Hence, the question of how to treat saline alkali soil has attracted widespread attention around the world. In recent years, it was demonstrated that using biological means to treat soil salinization is highly efficient, and environmental and sustainable, thus providing a new breakthrough method for saline alkali land treatment.

E. angustifolia, a member of the family, Elaeagaceae, is a deciduous tree that is widespread in the vast desert and semidesert in the Northwest of China. A few varieties of the species, E. angustifolia, 
can survive in the Gobi, such as the desert and saline, and is called the "treasure tree" locally. It is important to further improve the salt tolerance of E. angustifolia using biotechnology under saline-alkali conditions. Arbuscular mycorrhizal fungi (AMF) exist widely in soil and form a mutualism system with most higher plants [4,5]. Plants are subjected to salt stress in the presence of a high salinity in the soil, which reduces the absorption and transport of water, inhibits the metabolic process, and affects nutrient absorption and the cell infiltration balance, resulting in the fragmentation of the horny layer of plants and leakage of the cell membrane. This leads to plant growth retardation. AMF can adapt to the saline soil habitat and survive in a heavy salt environment, indicating that AMF is adaptable to saline soil [6]. Previous studies have shown that symbiosis between AMF and plants under salt stress can promote plant growth and improve plant salt tolerance $[7,8]$. Therefore, the symbiosis of halophytes with AMF has great potential for the improvement of salt resistance and restoration of saline-alkali land, which has been a major research field globally.

Previous studies on the application of proteomics technology revealed the salt tolerance of plant leaves [9-15]. However, the response mechanism of mycorrhizal plants to salt stress needs to be further revealed. In this study, the symbiosis of AMF Rhizophagus irregularis (RI) and the salt-tolerant plant, E. angustifolia, was used as a breakthrough point. The stress-responsive proteomics in the leaves of E. angustifolia were detected under salt stress conditions. These results will provide more information for the understanding of the function of AMF in the improvement of plant salt tolerance.

\section{Results}

\subsection{Growth of E. angustifolia under Salt Stress and Colonization of AMF in the Plant Roots}

As shown in Figure 1A, both mycorrhizal and non-mycorrhizal seedlings grew well in the treatments lacking salt, but the mycorrhizal seedlings' leaves grew stronger than the non-mycorrhizal seedlings; some leaves of the mycorrhizal and non-mycorrhizal seedlings were yellow during salt stress, however, the number of withered leaves of the mycorrhizal plants was significantly less than that of the non-mycorrhizal plants.

A
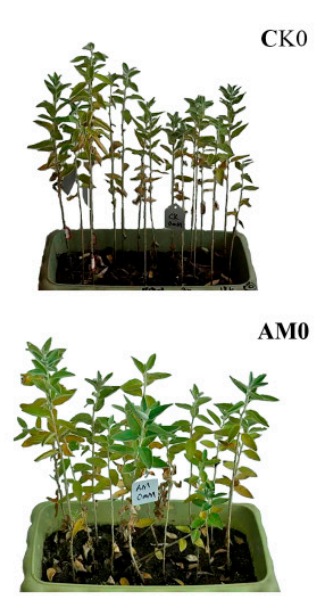

B

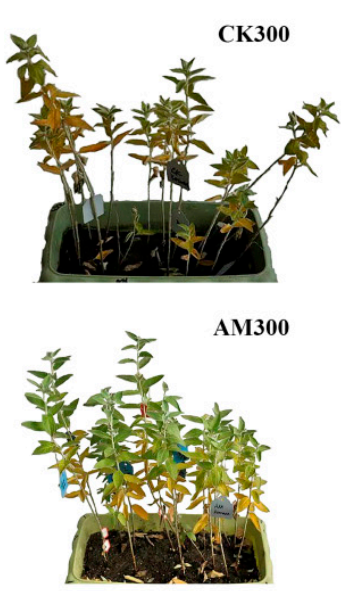

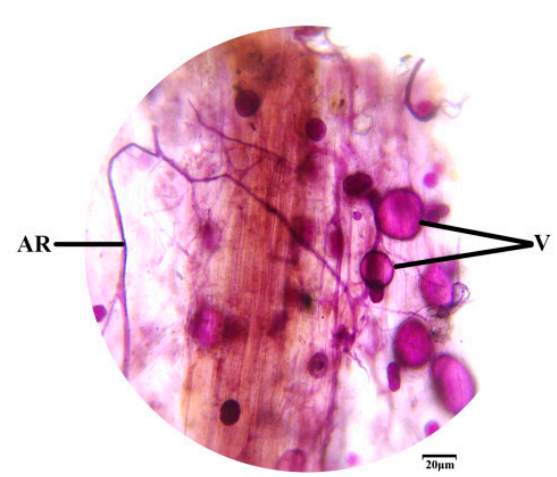

Figure 1. Growth of E. angustifolia inoculated AMF (arbuscular mycorrhizal fungi) under salt stress and a representative image of AMF colonization. Note: (A) represents the growth contrast in mycorrhizal and non-mycorrhizal E. angustifolia after salt stress. (B) represents a photomicrograph of the structural colonization of AMF in the root of $R$. irregularis. AM, mycorrhizal; CK, non-mycorrhizal; $0 \mathrm{mmol} / \mathrm{L}$, without salt stress; $300 \mathrm{mmol} / \mathrm{L}$, during salt stress; AR: Arbuscule; V: Vesicles. Scar bar: $20 \mu \mathrm{m}$.

The typical AMF morphological structure was detected in inoculated E. angustifolia roots, including vesicles and arbuscules (Figure 1B). The maximum AMF colonization percentage of the root reached more than $90 \%$ at approximately 100 at approximately 30 days after inoculation. The maximum 
AM colonization percentage of the root reached more than $90 \%$ at approximately 30 days after salt stress. At the same time, no colonization was found in the non-inoculated seedlings. This result shows that $E$. angustifolia and $R$. irregularis established a vigorous symbiosis.

\subsection{Effects of RI and CK on Height, Diameter, and Roots of E. angustifolia under Salt Stress}

Salt stress decreased the height, diameter, length, and area, but mycorrhizal seedlings had a greater height, diameter, length, and area than non-mycorrhizal seedlings during salt stress (Table 1). During the $300 \mathrm{mmol} / \mathrm{L} \mathrm{NaCl}$ treatment, the height, diameter, length, and area of the mycorrhizal seedlings increased by $9.1 \%, 20.8 \%, 17.4 \%$, and $35.5 \%$, respectively, compared with those of the nonmycorrhizal seedlings. AMF inoculation significantly enhanced the growth parameter of E. angustifolia seedlings in the presence of $300 \mathrm{mmol} / \mathrm{L} \mathrm{NaCl}$.

Table 1. Effects of RI and CK on the height, diameter, and roots of E. angustifolia under salt stress.

\begin{tabular}{|c|c|c|c|c|c|}
\hline $\begin{array}{c}\text { Level of } \\
\text { Salinity/(mmol/L) }\end{array}$ & $\begin{array}{l}\text { Different } \\
\text { Treatment }\end{array}$ & Height/(cm) & Diameter/(mm) & Length/(cm) & Area/ $\left(\mathrm{cm}^{2}\right)$ \\
\hline \multirow[b]{2}{*}{0} & $\mathrm{CK}$ & $45.50 \pm 0.24 c$ & $5.65 \pm 0.17 b$ & $985.73 \pm 27.80 b$ & $146.04 \pm 5.98 c$ \\
\hline & $\begin{array}{c}\text { RI } \\
\text { Significance }\end{array}$ & $49.07 \underset{* *}{ \pm 0.54 a}$ & $\underset{* *}{ \pm 0.20 \mathrm{a}}$ & $\underset{* *}{1256.7} \underset{*}{22.52 a}$ & $\underset{* *}{213.07} \pm 13.04 \mathrm{a}$ \\
\hline \multirow{3}{*}{300} & $\mathrm{CK}$ & $39.57 \pm 0.26 f$ & $3.99 \pm 0.14 \mathrm{e}$ & $763.64 \pm 23.34 \mathrm{e}$ & $93.68 \pm 6.27 \mathrm{e}$ \\
\hline & RI & $43.17 \pm 0.21 \mathrm{de}$ & $4.82 \pm 0.11 d$ & $\begin{array}{l}896.56 \pm \\
42.36 \mathrm{bcd}\end{array}$ & $126.96 \pm 8.03 \mathrm{~cd}$ \\
\hline & Significance & $* *$ & $* *$ & * & $* *$ \\
\hline
\end{tabular}

RI, mycorrhizal; CK, non-mycorrhizal; 0 mmol/L, without salt stress; $300 \mathrm{mmol} / \mathrm{L}$, during salt stress. Data are means \pm SD (standard deviation) of six replicates. The same letter within each column shows no significant differences among treatments $(p<0.05)$. Levels of significance: ${ }^{*} p<0.05,{ }^{* *} p<0.01$.

\subsection{Effects of RI and CK on the Soluble Sugar Content, Soluble Protein Content in the Leaves of E. angustifolia} under Salt Stress

As shown in Figure 2A, salinity stress caused a significant decline in the leaf soluble protein content of mycorrhizal and non-mycorrhizal seedlings, while mycorrhizal seedlings had a higher leaf soluble protein content than non-mycorrhizal seedlings during salt stress treatments. As shown in Figure $2 \mathrm{~B}, \mathrm{AMF}$ inoculation significantly promoted the leaf soluble sugar content in the treatments lacking salt. The soluble sugar content in the leaves of mycorrhizal and non-mycorrhizal seedlings increased, but mycorrhizal seedlings had a higher leaf soluble sugar content than that of the non-mycorrhizal seedlings during salt stress.

\subsection{Effect of RI on Protein Abundance under Salt Stress}

In the $\mathrm{CK}, \mathrm{AM}-\mathrm{NaCl}, \mathrm{AM}$, and $\mathrm{AM}-\mathrm{NaCl}$ groups, a total of 25,082 peptides and 4349 proteins were identified in the E. angustifolia seedlings. The number of proteins identified in the three replicates of each treatment group is shown in Figure 3. Quantifiable proteins were identified in at least two of the three replicates for further analysis. The significance of the differential proteins' abundances was filtered by the ratio $> \pm 2$ and $p$ value $<0.05$. The numbers of the differentially abundant proteins between treatments ( $\mathrm{NaCl}$ vs $\mathrm{CK}, \mathrm{AM}$ vs $\mathrm{CK}, \mathrm{AM}+\mathrm{NaCl}$ vs $\mathrm{AM}$, and $\mathrm{AM}+\mathrm{NaCl}$ vs $\mathrm{NaCl}$ ) are shown in Table 2. 
A

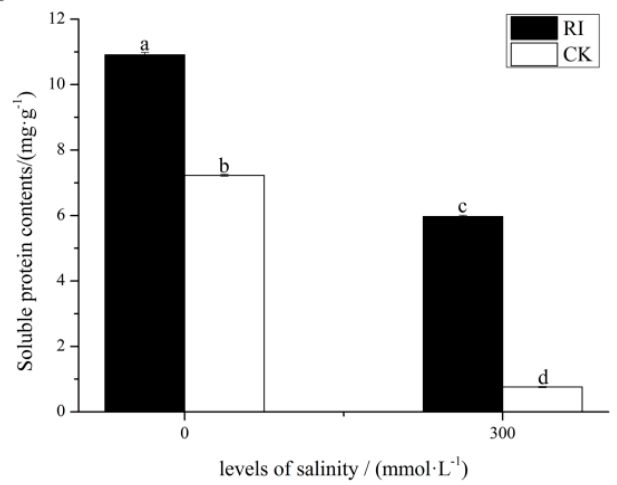

B

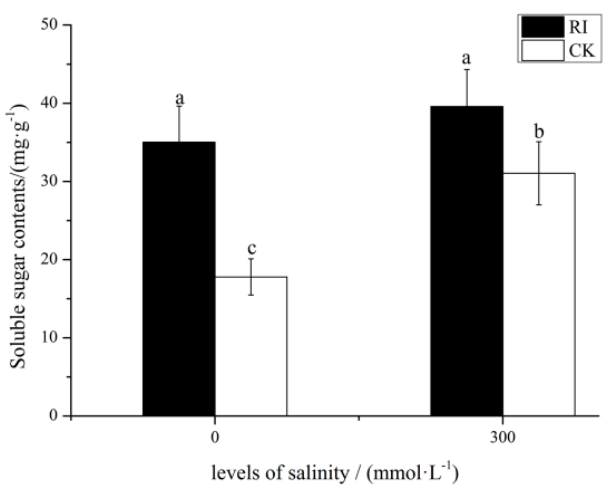

Figure 2. Effects of RI and CK on the soluble sugar content and soluble protein content in the leaves of E. angustifolia under salt stress. Note: (A) soluble protein, (B) soluble sugar. RI, mycorrhizal; CK, non-mycorrhizal; $0 \mathrm{mmol} / \mathrm{L}$, without salt stress; $300 \mathrm{mmol} / \mathrm{L}$, during salt stress. Columns represent the means for three replicates $(n=3)$. Error bars show the standard error. Columns with different letters indicate significant differences between the treatments at $p<0.05$.

A

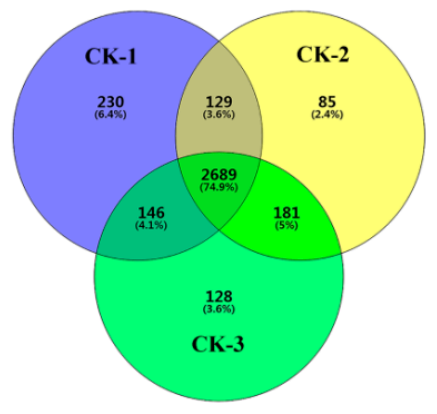

C

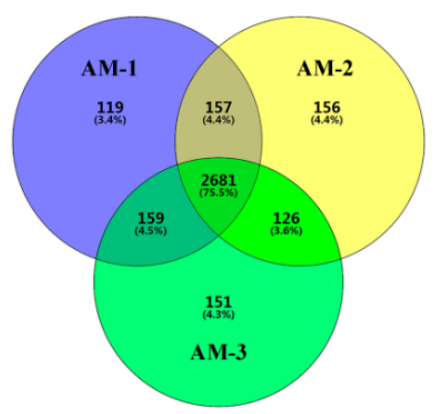

B

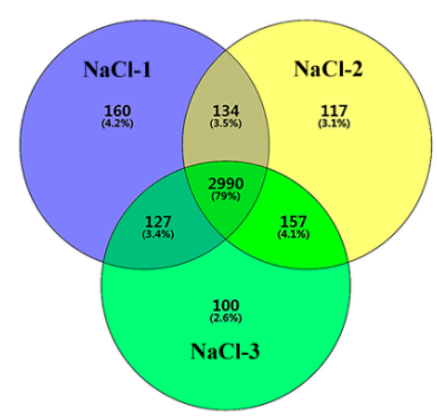

D

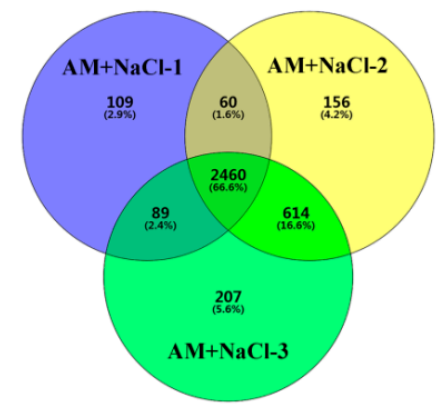

Figure 3. Statistics of the number of proteins identified in each treatment group. Note: (A) the number of proteins identified in the three replicates of CK group; (B) the number of proteins identified in the three replicates of $\mathrm{NaCl}$ group; (C) the number of proteins identified in the three replicates of AM group; (D) the number of proteins identified in the three replicates of $\mathrm{AM}+\mathrm{NaCl}$ group.

Table 2. Differentially expressed proteins between treatments.

\begin{tabular}{cc}
\hline Treatments & Number of Differential Proteins \\
\hline $\mathrm{NaCl}$ vs CK variation analysis & $402 \mathrm{a}+335 \mathrm{~b}$ \\
$\mathrm{AM}$ vs CK variation analysis & $35 \mathrm{a}+152 \mathrm{~b}$ \\
$\mathrm{AM}+\mathrm{NaCl}$ vs AM variation analysis & $166 \mathrm{a}+226 \mathrm{~b}$ \\
$\mathrm{AM}+\mathrm{NaCl}$ vs NaCl variation analysis & $62 \mathrm{a}+189 \mathrm{~b}$ \\
\hline
\end{tabular}

a: The number of proteins was the satisfied condition (ratio $> \pm 2$ and $p$ value $<0.05$ ); $b$ : The number of proteins was only detected at $\mathrm{CK}$ or treatments $(\mathrm{NaCl}, \mathrm{AM}, \mathrm{AM}+\mathrm{NaCl})$. 


\subsection{Functional Classification of Proteins}

\subsubsection{Salt Tolerance-Related Proteins Induced by Symbiosis}

As shown in Table 2, a total of 187 differentially expressed proteins were identified in the AM vs the CK group. The 186 proteins were compared with the $\mathrm{AM}+\mathrm{NaCl}$ vs the AM group; a total of 112 were found in the $\mathrm{AM}+\mathrm{NaCl}$ vs the AM group. Among the 112 proteins, four proteins were highly abundant, 25 were newly expressed proteins under salt stress, and 14 proteins were identified as symbiotic salt tolerance related proteins after referring to many academic documents, as shown in Table A1. These 14 proteins are beneficial to the maintenance of AMF-E. angustifolia symbiosis and improved the salt tolerance of the plant under salt stress.

\subsubsection{Functional Classification of Salt Tolerance-Related Proteins Induced by Symbiosis}

Blast2GO (Version 3.3.5) was used to annotate the biological functions of the targeted proteins. These proteins were divided into seven groups (Figure 4), including metabolism, signal transduction, redox, transport, cytoskeleton, protein synthesis, protein folding, and degradation (Table A1). Among them, the proportion of metabolic and protein folding related proteins were the largest, which was $22 \%$. The second category was related to redox, transport, and cytoskeleton, which was $14 \%$. The third category included signal transduction-related and protein synthesis proteins.

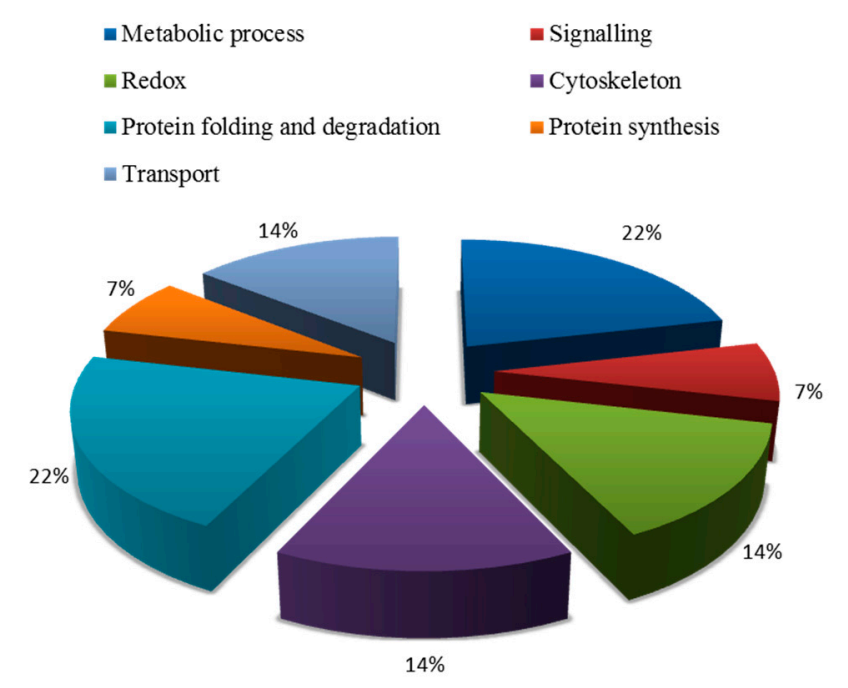

Figure 4. Biological functional classification of salt-tolerant proteins induced by symbiosis.

\subsubsection{Salt-Induced Mycorrhizal Protein}

As shown in Figure 5, after a comparison of differentially expressed proteins between $\mathrm{NaCl}$ vs $\mathrm{CK}$ and AM + NaCl vs AM groups by VENNY 2.1 (http://bioinfogp.cnb.csic.es/tools/venny/index.html), 121 out of 392 proteins in the $\mathrm{AM}+\mathrm{NaCl}$ vs AM group were identical with those in the $\mathrm{NaCl}$ vs CK group. It is suggested that these 121 proteins are salt-tolerant related proteins of E. angustifolia under salt stress, and are not caused by mycorrhizal. However, 271 proteins not in the $\mathrm{NaCl}$ vs $\mathrm{CK}$ group were considered to be salt-induced mycorrhizal proteins. The mycorrhizal proteins produced by AMF-E. angustifolia symbiosis to adapt to salt stress under salt stimulation. Thus, the salt tolerance of plants can be improved. 


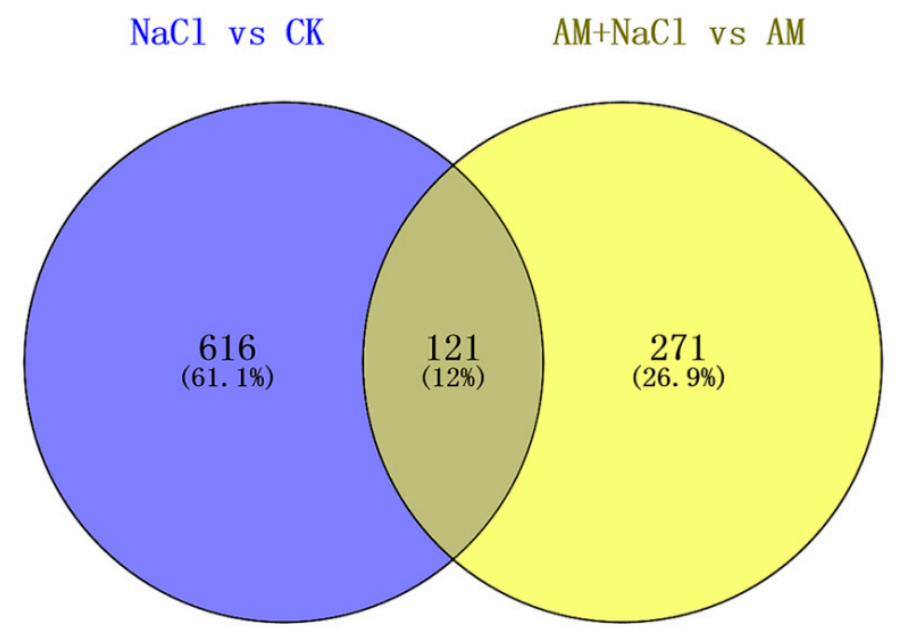

Figure 5. Venn diagram of the protein differential expression between the $\mathrm{NaCl} / \mathrm{CK}$ group and $\mathrm{AM}+$ $\mathrm{NaCl} / \mathrm{AM}$ group.

\subsubsection{Functional Classification of Salt-Induced Mycorrhizal Protein}

A total of 57 out of 271 proteins were previously reported to be key proteins for the salt response, as shown in Table A2. These were divided into 10 groups by Blast 2 GO analysis (Figure 6). In these functional groups, the first class $(23 \%)$ are proteins related to metabolism. There are nine (accounting for $14 \%$ ) different expressed proteins in the signal transduction pathway, which is the second class. Meanwhile, the other 10 functional groups are also involved in protein redox, protein synthesis, photosynthesis, energy, transport, the cytoskeleton, and stress response related proteins.

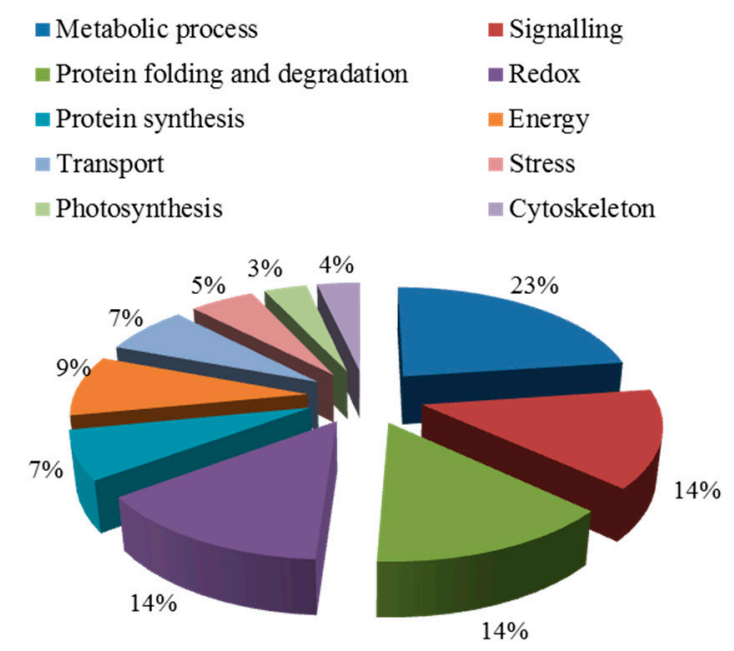

Figure 6. Biological functional classification of salt-induced mycorrhizal protein.

\section{Discussion}

AMF and salt affected the obvious physical appearance of E. angustifolia leaf, and both have a clear interaction. For this reason, we think that AMF has a great influence on salt habitats and that, moreover, salt stress is also a factor in this influence. On the one hand, compared with the AM vs $\mathrm{CK}$ group and the $\mathrm{AM}+\mathrm{NaCl}$ vs $\mathrm{AM}$ group, the salt-tolerant proteins caused by the symbiosis could be identified; on the other hand, by comparing the differentially abundant proteins of the $\mathrm{NaCl}$ vs $\mathrm{CK}$ group and the $\mathrm{AM}+\mathrm{NaCl}$ vs $\mathrm{AM}$ group, the protein for the symbiosis response caused by salt treatment could be identified. Therefore, these two ways were selected to discuss how symbiosis responds to salt stress at the protein level (Figure 7). 


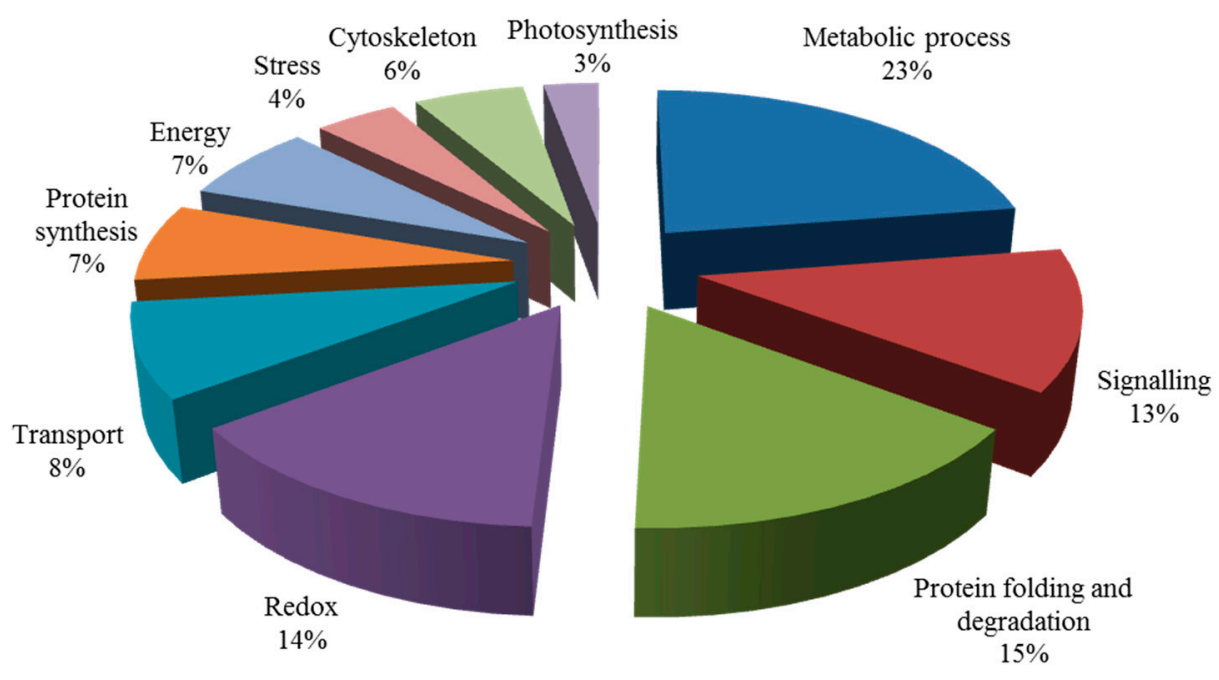

Figure 7. Biological functional classification of differential proteins.

\subsection{Proteins Related to Metabolism}

Metabolism, consisting of basic physiological processes, maintains a series of activities of a living organism. This research shows the most important factor in the leaves of the E. angustifolia after salt stress was the abundance of secondary metabolism-related proteins. In secondary metabolism, especially the metabolism of the protein, phenylpropane and flavonoids increased significantly under salt stress.

Studies have shown that secondary metabolites of plants change during the symbiosis of mycorrhizal fungi and plants [16]. These secondary metabolites play an important role in the symbiotic relationship between plants and mycorrhizal fungi [17]. For example, the content of lignin and soluble phenol in the tomato was increased by inoculation with Arbuscular mycorrhizal fungi. Flavonoids can promote spore germination and mycelium growth and increase the content of flavonoids after mycorrhizal formation $[18,19]$. In this study, there were two pathways involved in metabolism-related proteins, as shown in Figure 8.

1. In this study, we found a chorismate mutase (CM), which catalyzes the conversion of branched acid to prebenzoic acid. Prebenzoic acid can produce phenolic compounds through the phenylpropane metabolic pathway, including phenylalanine (Phe), tyrosine (Tyr), anthocyanin, and tannin [20,21]. Phenylpropane metabolism is indirectly generated by the shikimic acid pathway. This pathway might play an important role in plant stress defense. We found three proteins that relate to the phenylalanine metabolic pathways, including shikimate O-hydroxycinnamoyltransferase, cinnamyl alcohol dehydrogenase, and caffeoyl-CoA O-methyltransferase. Flavonoids are synthesized by the condensation of phenylpropane derivatives with malonate monoacyl coenzyme A. In addition, shikimic acid O-hydroxyacinnamate transferase and caffeoyl coenzyme A-O-methyltransferase were also involved.

2. In this study, we found that the phosphoribosyltransferase (APT) was up-regulated, which was the first key enzyme in the tryptophan production reaction of o-aminobenzoic acid. Phosphorylribosyltransferase activity of o-aminobenzoic acid was enhanced, which accelerated the synthesis of tryptophan in plants under salt stress. It is well known that tryptophan is a precursor of auxin (indole acetic acid) as well as protein synthesis in plants. Auxin response was also identified in the leaves of E. angustifolia. We deduced that these two pathways synthesize auxin to maintain the growth and metabolism of mycorrhizal plants under salt stress. 


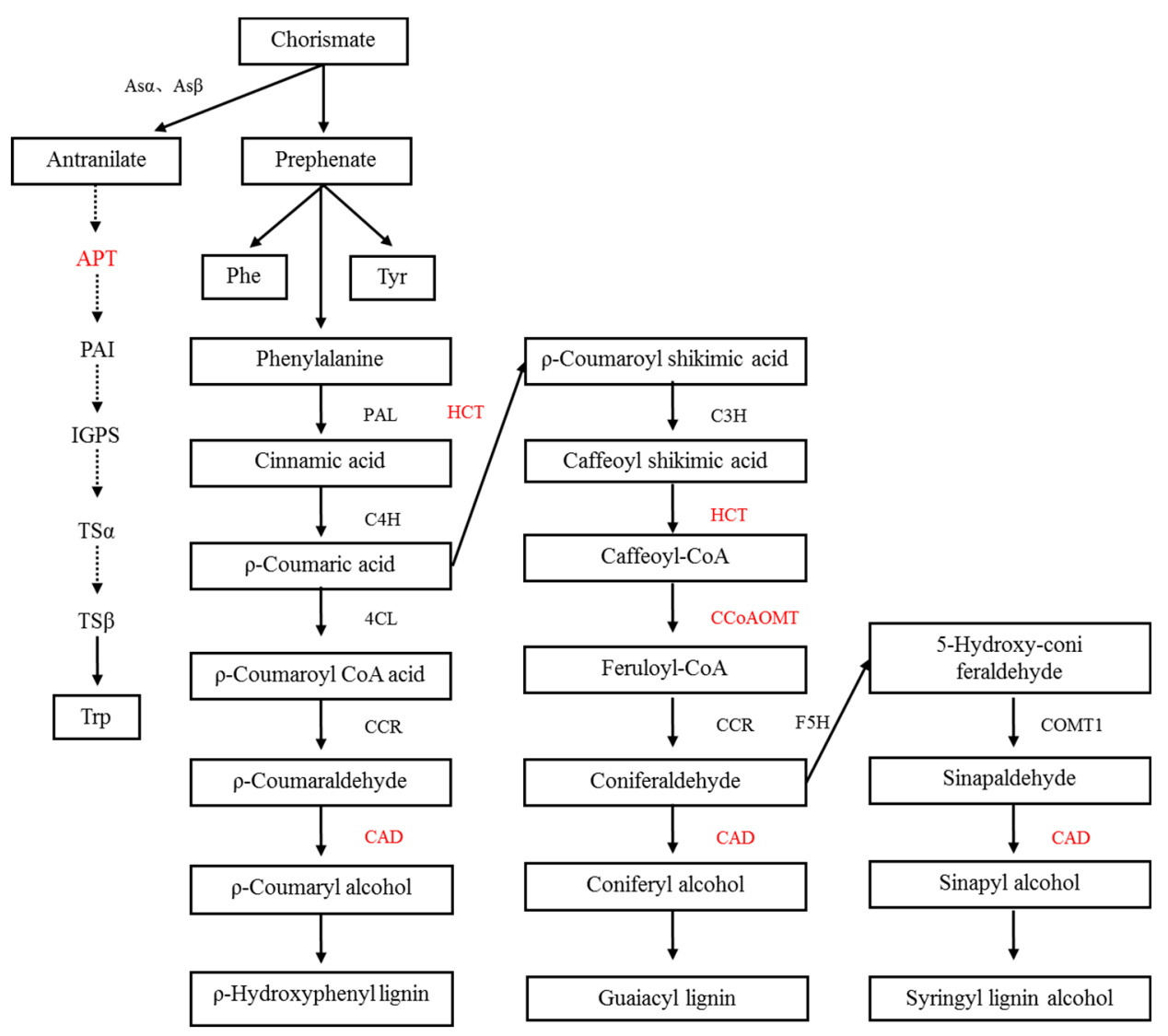

Figure 8. Secondary metabolism of the alleviation of salt stress in mycorrhizal E. angustifolia seedlings. Note: red color items represents proteins related to secondary metabolism in this study.CM: chorismate mutase; APT: anthranilate phosphoribosyltransferase; HCT: shikimate O-hydroxycinnamoyltransferase; CAD: cinnamyl alcohol dehydrogenase; CCoAOMT: caffeoyl-CoA O-methyltransferase.

Alkaline neutral invertase is involved in the decomposition of sucrose into glucose and fructose and plays an important role in plant growth and development. The study showed that $\mathrm{NaCl}$ and PEG (Polyethylene glycol) stress increased the differential expression of sugar cane SoNIN1 in the root and leaf [22], and the alkaline neutral transformation enzyme was involved in the stress response. This study found that after inoculation of AMF to the E. angustifolia leaf in the treatment of salt stress, alkaline neutral invertase increased its expression, thereby improving the soluble sugar content of the E. angustifolia leaf, and providing more sugar for plant metabolism.

\subsection{Protein Synthesis, Folding, and Degradation Related Proteins}

Protein synthesis plays an important role in plant growth under abiotic stress. We found two proteins (ubiquitin-60S ribosomal L4 and 60S acidic ribosomal P1) were up-regulated in the mycorrhizal plant. Similar ribosomal proteins were also found in studies [23]. One study showed that mitochondrial elongation factors can extend peptide chains more [24], and this was also found to be up-regulated in this study. These proteins related to protein synthesis increase the tolerance of the mycorrhizal plant to salt stress by increasing the expression level.

Proteins can lose their biological functions due to denaturation under adverse conditions. Correct folding and degradation of proteins are key to the maintenance of normal cell functions. Molecular chaperones and folding enzymes play an important role in the maintenance of the natural conformation of proteins, which can help them fold correctly $[23,25]$. In this study, we found that four folding enzymes, peptide-based prolyl cis-trans isomerases, and four molecular chaperones were up-regulated under salt stress, including peptidyl-prolyl cis-trans isomerase FKBP12, FKBP-type peptidyl-prolyl cis-trans isomerase 5 isoform 1, peptidyl-prolyl cis-trans isomerase CYP18-1, peptidyl-prolyl cis-trans 
isomerase FKBP62, prefoldin subunit 1, prefoldin subunit 2, heat shock $70 \mathrm{kDa}$ partial, and small heat shock protein $17.3 \mathrm{kDa}$. Therefore, the up-regulation of these four peptidyl prolyl cis-trans isomerases and four molecular chaperones completes the correct folding of proteins and helps the mycorrhizal E. angustifolia resist salt stress.

E3 ubiquitin ligase (UPL3) and ubiquitin-like 1-activating enzyme (E1 B) increased their expression under salt stress. Studies have shown that E3 ubiquitin protein ligase, ubiquitin activation enzyme E1, and ubiquitin ligase all catalyze ubiquitin to their target proteins. Moreover, the specificity of the ubiquitin pathway is controlled by E3, which is pertinent because it can provide the greatest response to environmental stress by regulating the transcription factor of the downstream stress response [26].

\subsection{Signal Transduction-Related Proteins}

Plants exposed to an adverse environment for a long time will produce a complex system of signal sensing and transduction. It is particularly important to understand how mycorrhizal plants perceive and transmit this stress signal, as well as method of improving the plant salt tolerance under salt stress.

In this study, a series of proteins related to signal transduction were screened out, including $\mathrm{G}$ protein, phospholipase $\mathrm{C}$, plasma membrane $\mathrm{Ca}^{2+}$ transporter ATPase (PMCA), calcium-dependent protein kinase (CDPKs), calmodulin (CaM), and calcium binding (CML), and were up-regulated. They communicated with each other, thus completing the process of perceiving and transmitting stress signals.

G protein, also known as signal-converting protein or coupling protein, can specifically bind and recognize signals on the cell membrane, and produce intracellular signals with the medial membrane effector enzyme (phospholipase C), which plays a role in signal transduction. After transmembrane conversion, extracellular signals are further transmitted and expanded through $\mathrm{Ca}^{2+}$ (second messenger) signals, which eventually lead to a series of physiological and biochemical reactions in cells. $\mathrm{Ca}^{2+}$ participates in metabolic pathways that are mainly dependent on changes in the $\mathrm{Ca}^{2+}$ concentration [27], and this process is achieved by the various calcium transport systems distributed in the cell organelles and cell membranes [28]. The changes in the $\mathrm{Ca}^{2+}$ concentration in the various processes in this study depended on the plasma membrane $\mathrm{Ca}^{2+}$ transporter, ATPase (PMCA), which is the main $\mathrm{Ca}^{2+}$ transporter, transporting $\mathrm{Ca}^{2+}$ to the extracellular space at the cost of hydrolyzing an ATP molecule. Studies have shown that the calcium-dependent protein kinase (CDPKs), calmodulin, calmodulin, and the calcium phosphatase B protein, are involved in cell signal transduction and responses to specific stimuli $[29,30]$. In this study, the $\mathrm{Ca}^{2+}$ concentrations maintained a steady state in the cell wall, mitochondria, endoplasmic reticulum, and vacuole, while the concentration in the cytoplasm was low. After salt stimulation, the $\mathrm{Ca}^{2+}$ concentration in the cytoplasm increased significantly. On the one hand, $\mathrm{Ca}^{2+}$ directly binds to the calmodulin or the calmodulin, transfers the received signal to the protein kinase and stimulates its activity, or the activity of calcium depends on the protein kinases (CDPKs), which are directly stimulated by the $\mathrm{Ca}^{2+}$ signal, and directly participate in and cause subsequent physiological responses through these two processes. These two processes directly participate in and cause subsequent physiological responses.

\subsection{ROS Scavenging-Related Proteins}

Active oxygen species (ROS) are usually accumulated in plants under salt stress [31], which can be used as signal molecules to activate the plant stress defense system [32]. However, all ROS are very harmful to organisms at high concentrations, leading to cell membrane peroxidation, destruction of enzyme activity, and eventually leading to cell inactivation. Therefore, the removal of ROS can resist salt damage and improve the salt tolerance of plants. In this study, thioredoxin (TRX) and glutathione (GRX) were involved in ROS scavenging as redox enzymes. In these plants, based on the TRX redox system that runs in various kinds of organelles, including the cytoplasm, mitochondria, and chloroplasts [33-36], it was shown that TRX plays a key role in plant redox regulation. At present, many GRXs have been identified in different plants. For example, over-expression of the tomato 
SLGRX1 gene can enhance the plant's resistance to oxidative stress, drought resistance, and salt pollution in Arabidopsis. In contrast, silencing this gene leads to an increased insensitivity to stress in the tomato [37]. Meanwhile, the gene silencing increases the membrane lipid peroxide level and the accumulation of ROS and suppresses the activity of antioxidant enzymes under high-temperature stress. This suggests that GRXs are involved in the regulation of the redox status and the response to high-temperature stress.

In our study, three glutathione s-transferase (GST) and two glutathione peroxidase (GPX) were found. Studies have reported that to prevent ROS damage, the amount of glutathione transferase (GST) in plants will increase, which can catalyze the removal of ROS in plants [38]. Glutathione peroxidase (GPX) is a sulfur-containing peroxidase, which can remove hydrogen peroxide, organic hydroperoxides, and lipid peroxides from the organism, and block further damage of ROS to the organism [39,40]. It has been shown that chloroplast glutathione transferase plays a very important role in the resistance of low concentrations in Stargrass seedlings [41]. When plants are exposed to high salt stress, the expression activity of GPX will be enhanced and the tolerance of plants to salt stress will be enhanced [42-44]. In addition, excessive expression of GST/GPX in transgenic tobacco under salt stress conditions for seed germination and seedling growth were improved more than for the control group, suggesting that GST/GPX increases the ROS removal in plants, protects plants from oxidative damage, and maintains the growth of plants $[45,46]$. These results suggest that the GST/GPX system is a key factor in the improvement of the salt tolerance of plants through its ROS scavenging ability under salt stress. Peroxidase (POD) is one of the key enzymes in plants under stress conditions in the enzymatic defense system. It cooperates with superoxide dismutase and catalase to remove excess ROS to improve plant resistance.

"Arbuscular Mycorrhizal Symbiosis Modulates Antioxidant Response and Ion Distribution in Salt-Stressed Elaeagnus angustifolia Seedlings"- Changes of SOD, CAT, POD, and APX activities in the leaves of E. angustifolia inoculated with AMF and those of non-inoculated E. angustifolia under 0 and 300 salt concentrations were analyzed [47].

As shown in Figure 9, mycorrhizal seedlings had a higher leaf SOD (superoxide dismutase), CAT (Catalase), POD (Peroxidase), and APX (ascorbate peroxidase) activity than that of the non-mycorrhizal seedlings during salt stress. The mycorrhization of the plants led to increased levels of leaf antioxidant defense systems during stress conditions. The results obtained at the protein level are consistent with the results of the apparent physiological indicators in this study. Therefore, we can conclude that TRX/GRX, GST/GPX, and POD are up-regulated in mycorrhizal plants under salt stress, which results in a significant increase of SOD, CAT, POD, and APX activities in plant leaves, thus improving the salt tolerance of mycorrhizal plants.

\subsection{Energy-Related Protein}

Mitochondria are the main site of oxidative phosphorylation and the synthesis of adenosine triphosphate (ATP) in cells, and they provide energy for cell activity. NADH dehydrogenase, cytochrome $\mathrm{C}$ oxidase, iron sulfur protein NADH dehydrogenase, and ATP synthase up-regulation were found in this study as complex compounds I, IV, and V participated in the mitochondrial electron transport. The mitochondrial electron transport chain is also called the respiratory chain, and the cells transfer electrons obtained from the oxidation of macromolecules via I, II, III, and IV complexes and the energy produced by the electron transfer maintains the proton gradient of the mitochondrial inner membrane, which is utilized by complex V (ATP synthase) to catalyze the formation of ATP. In this study, proteins involved in providing cellular energy were up-regulated to provide energy for mycorrhizal plants to resist salt stress. 

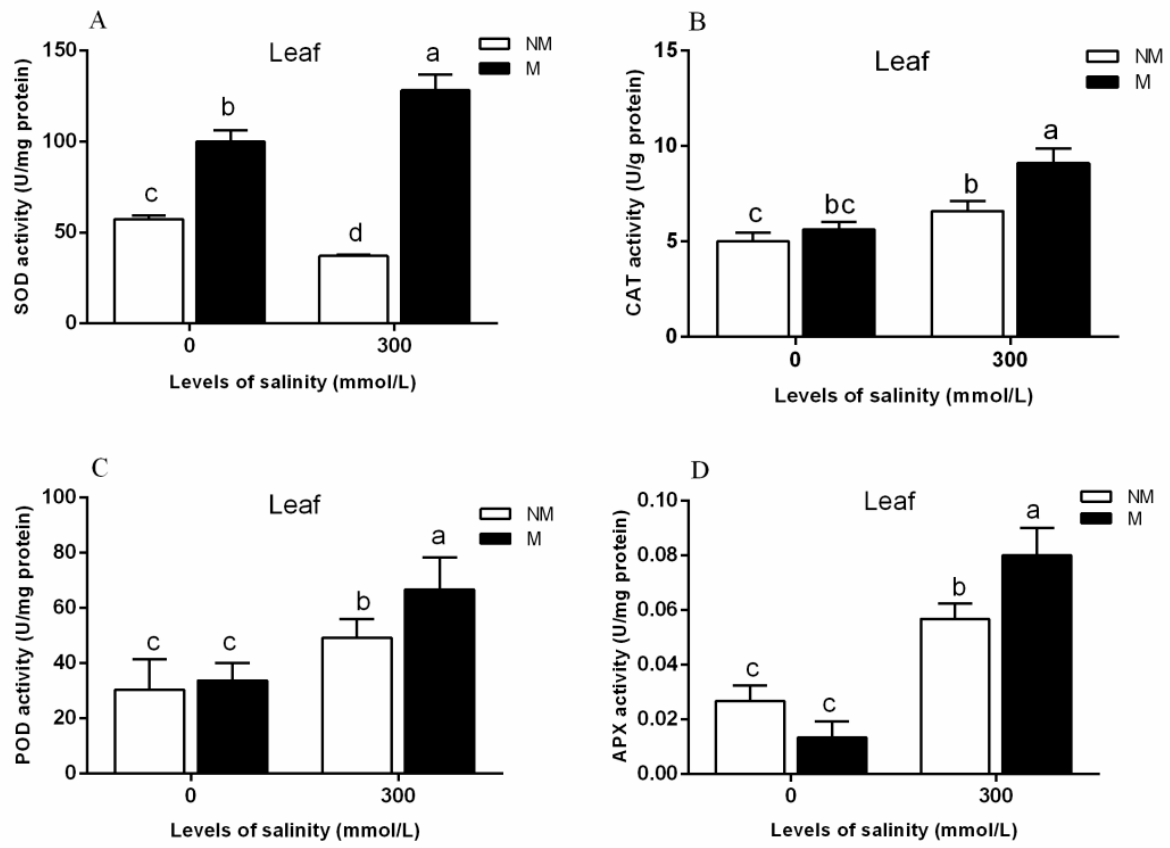

Figure 9. Effects of AMF inoculation on the superoxide dismutase (SOD) (A), catalase (CAT) (B), peroxidase (POD) (C), and ascorbate peroxidase (APX) (D) activities in the leaves during different salt conditions. M, mycorrhizal; NM, non-mycorrhizal; 0 mmol/L, without salt stress; $300 \mathrm{mmol} / \mathrm{L}$, during salt stress. Columns represent the means for three plants $(n=3)$. Error bars show the standard error. Columns with different letters indicate significant differences between treatments at $p<0.05$. Note: cited from “Arbuscular Mycorrhizal Symbiosis Modulates Antioxidant Response and Ion Distribution in Salt-Stressed Elaeagnus angustifolia Seedlings" [47].

\subsection{Photosynthesis-Related Proteins}

AMF and plant symbiosis can promote plant growth by increasing the photosynthesis of plants under salt stress, thereby increasing the ability of plants to resist the salt stress [48-53]. In this study, a photosystem II D1 precursor processing PSB27 was found to have upregulated expression. Photosystem II D1 protein is the core protein of photosystem II, which is synthesized in light and is injured by light or other adverse factors. Repairing D1 protein damage repairs PS II, maintaining its dynamic balance through continuous turnover $[54,55]$. In addition, the reactive center proteins, D1 and D2, are the binding sites of the auxiliary factors for all redox activities, which are necessary for PSII electron transport $[54,56]$. Thus, the photosystem II D1 protein plays an important role in the maintenance of the stability of the PSII reaction center. The previously mentioned thioredoxin (TRX), which is electronically reduced by the ferredoxin/thioredoxin system (Fd/TRX) in the chloroplasts of plants, is involved in the electron transport of plant photosynthesis. Guo [57] and other studies found that GRXs gene-silenced plants resulted in a significant decrease in ETR of photosystem II, and a significant increase in NPQ in varying degrees. Meanwhile, GRXs gene silencing results in a significant decrease in the maximum quantum efficiency $(\mathrm{Fv} / \mathrm{Fm})$ and the actual electronic yield ( $\Phi$ PSII) under high temperature stress. This is consistent with the results of the chlorophyll fluorescence parameters in the early stage of this experiment [58], in which Fv/Fm, PSII, NPQ, and ETR in the leaves of E. angustifolia inoculated with AMF were higher than those of non-mycorrhizal plants under salt stress. In this study, TRX and GRX were up-regulated at the protein level, and Fv/Fm, PSII, NPQ, and ETR of mycorrhizal plants were significantly increased at the apparent level, thus alleviating the damage of salt stress to plants. 


\subsection{Network Interaction Predictions Based on Differential Expression}

The protein-protein interaction information of the studied proteins was retrieved from the IntAct molecular interaction database (http:/ / www.ebi.ac.uk/intact/) by their gene symbols or STRING software (http://string-db.org/). These interactions included the direct physical proteins and the indirect proteins correlated with indirect functions as shown in Figure 10. The results showed that ubiquitin-60S ribosomal was the most correlated protein, directly or indirectly, with connections to proteins, such as $60 \mathrm{~S}$ acidic ribosomal, elongation factor mitochondrial, ubiquitin-activating enzyme E1, and E3 ubiquitin-ligase. Additionally, most of the target proteins were associated with ubiquitin-60S ribosomal and were in the protein synthesis, folding, and degradation pathway. Thus, this pathway might play an important role in stress tolerance. Ubiquitin-60S ribosomal interacts with various peroxidases, thereby participating in E. angustifolia protein synthesis, folding, and degradation biosynthetic processes, and modulates stress responses. These findings showed that the salt stress response is a multi-factor process involving many protein interactions.

The hypothesized mechanism of the improved salt tolerance of the mycorrhizal plant was revealed from the proteome.

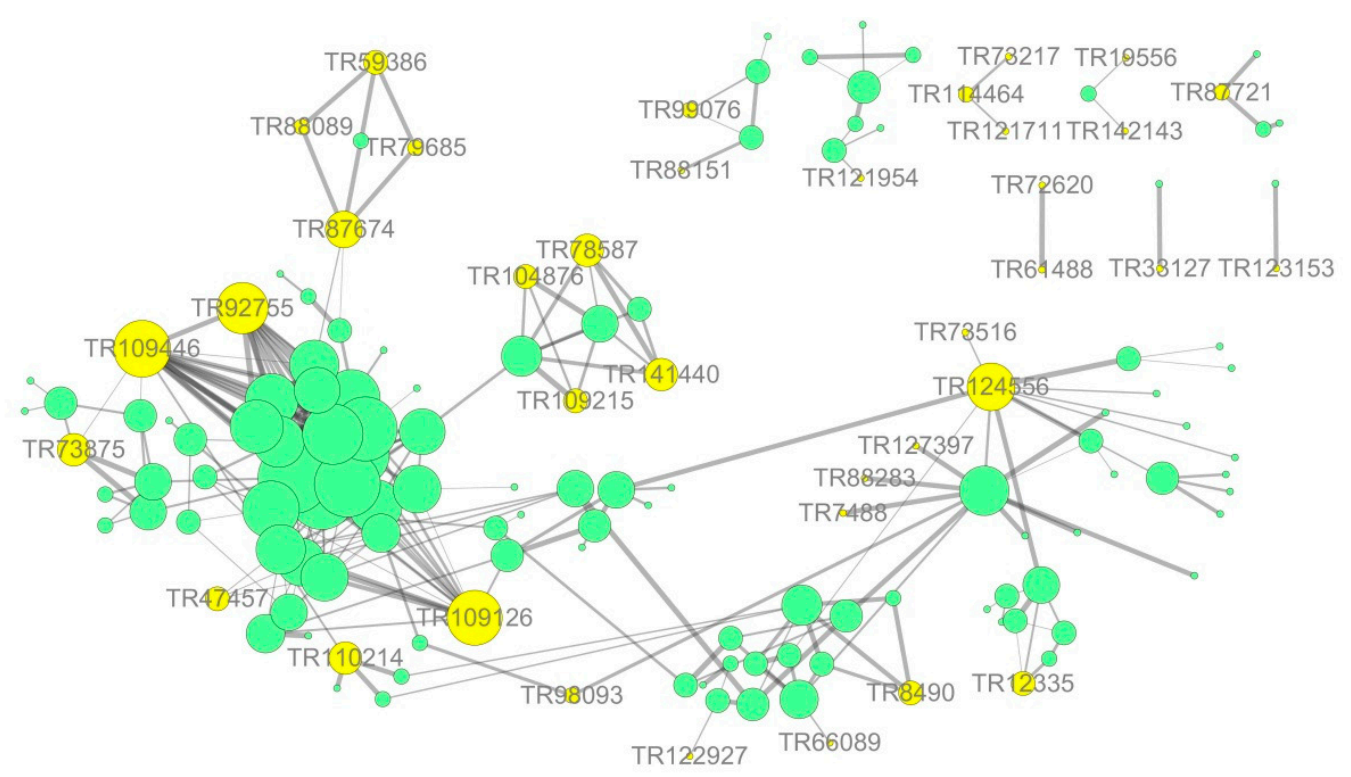

Figure 10. Protein-interaction network interactions for differentially expressed proteins. Note: shows the integrated network for all the differentially expressed proteins; yellow circle represents salt tolerance-related proteins induced by symbiosis and salt-induced mycorrhizal protein in this study; green circle represents other differentially expressed proteins in this study, respectively. The sizes represent the abundance of differentially expressed proteins.

In the current study, based on proteomic data analysis, it is suggested that AMF can improve the salt tolerance of E. angustifolia seedlings (Figure 11).

1. AMF accelerates the secondary metabolism of plants, mainly phenylpropanoid metabolism (shikimate O-hydroxycinnamoyltransferase, cinnamyl alcohol dehydrogenase, and caffeoyl-CoA O-methyltransferase), reducing salt damage to plants.

2. AMF enhances the signal transduction of the second messenger $\mathrm{Ca}^{2+}(\mathrm{G}$ protein, phospholipase $\mathrm{C}$, plasma membrane $\mathrm{Ca}^{2+}$ transporter ATPase (PMCA), calcium binding (CML), calcium-dependent kinases (CDPKs), and calmodulin (CaM), increasing the speed of sensing and transmitting of stress signals, allowing plants to follow up.

3. Among a variety of antioxidant pathways (TRX/GRX, GST/GPX, POD), AMF enhances the antioxidant capacity of plants by increasing ROS clearance. 
4. AMF promotes protein biosynthesis, speeding up protein folding, and inhibiting protein degradation (ubiquitin-60S ribosomal, 60S acidic ribosomal, elongation factor mitochondrial, ubiquitin activating enzyme E1, and E3 ubiquitin- ligase).

5. In the chloroplast, AMF maintains the PSII reaction centre conformation stability and speeds up photosynthetic electron transport (TRX/GRX, photosystem II D1 precursor processing PSB27chloroplastic); in mitochondria, AMF enhances the synthesis of ATP (NADH dehydrogenase, cytochrome $\mathrm{C}$ oxidase, iron sulfur protein NADH dehydrogenase, and ATP synthase), providing sufficient energy for cellular activities.

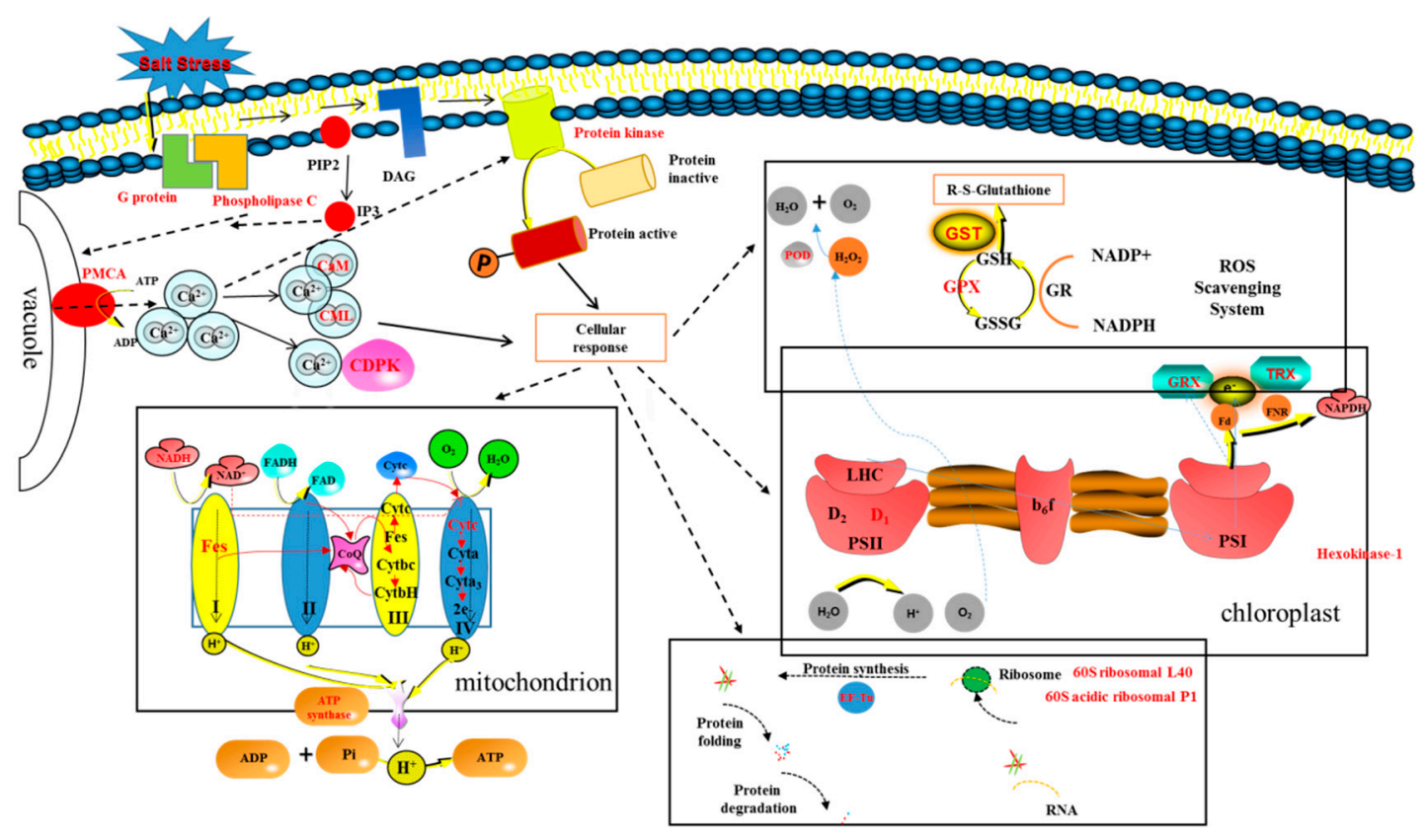

Figure 11. Mechanisms of mycorrhizal E. angustifolia seedlings to alleviate salt stress. Note: Protein folding and degradation: peptidyl-prolyl cis-trans isomerase FKBP12; FKBP-type peptidyl-prolyl cis-trans isomerase 5 isoform 1; peptidyl-prolyl cis-trans isomerase CYP18-1; peptidyl-prolyl cis-trans isomerase FKBP62; prefoldin subunit 1; prefoldin subunit 2; Heat shock $70 \mathrm{kDa}$ partial; small heat shock protein $17.3 \mathrm{kDa}$; E3 ubiquitin ligase (UPL3); ubiquitin-like 1-activating enzyme (E1 B). PMCA: calcium-transporting ATPase; CaM: calmodulin; CML: calcium-binding CML20; CDPK: calcium-dependent kinase; POD: peroxidase; GST: glutathione S-transferase; GPX: glutathione peroxidase; GRX:glutaredoxin; TRX:thioredoxin; D1:photosystem II D1 precursor processing PSB27; EF-Tu: elongation factor mitochondrial; NADH: NADH dehydrogenase [ubiquinone] 1 beta subcomplex subunit 7; Fes: NADH dehydrogenase [ubiquinone] iron-sulfur mitochondrial; Cytc: cytochrome c oxidase subunit mitochondrial.

\section{Materials and Methods}

\subsection{Experimental Materials and Salinity Treatments}

E. angustifolia seeds were provided by Heilongjiang Jinxiudadi Biological Engineering Co. Ltd. (Haerbin, China). AM fungus Rhizophagus irregularis (RI) was propagated and preserved by Heilongjiang Provincial Key Laboratory of Ecological Restoration. The mycorrhizal inoculum containing approximately 25-30 AM propagules/g consisted of soil, spores, mycelia, and infected root fragments. The soil was collected from the Forest Botanical Garden of Heilongjiang Province, sieved $(5 \mathrm{~mm})$, and mixed with vermiculite (3:1, soil:vermiculite, $v / v)$. The soil medium was pre-autoclaved at $121^{\circ} \mathrm{C}$ for $2 \mathrm{~h}$.

There were four different treatments as follows: E. angustifolia inoculated Rhizophagus irregularis without salt stress, E. angustifolia inoculated Rhizophagus irregularis under salt stress $(300 \mathrm{mmol} / \mathrm{L}$ 
$\mathrm{NaCl})$, E. angustifolia non-inoculated Rhizophagus irregularis without salt stress, and E. angustifolia non-inoculated Rhizophagus irregularis under salt stress $(300 \mathrm{mmol} / \mathrm{L} \mathrm{NaCl})$. Each treatment had six replicates. The inoculated dosage of mycorrhizal inoculum per pot was $10 \mathrm{~g}$. The same amount of inactive mycorrhizal inoculum $\left(121^{\circ} \mathrm{C}, 2 \mathrm{~h}\right)$ was used in non-inoculated treatments. The $300 \mathrm{mmol} / \mathrm{L}$ $\mathrm{NaCl}$ was added into the pots after 4 months of being inoculated with mycorrhizal inoculum as described [47]. Seedlings continued to be cultivated for 30 days. The experiment was carried out under outdoor natural conditions.

Three seedlings were randomly selected from each pot and 6-7 round leaves were removed from each seedling. Leaves from two pots of the same treatment were combined as one sample. There were three biological repeats per treatment. The proteomic, AMF colonization, and growth parameter of the samples was detected.

\subsection{Measurement of AMF Colonization and Growth Parameter}

The AMF colonization rate of E. angustifolia was determined by the acid fuchsin staining method [59]. The height and diameter of E. angustifolia were measured by a vernier caliper. The root area and root length of E. angustifolia were measured by a root scanner.

\subsection{Measurement of Soluble Sugar Content, Soluble Protein Content in the Leaves of E. angustifolia under Salt Stress}

To assess the degree of stress, the contents of sugar and soluble protein were detected using the anthrone colorimetric method and coomassie brilliant blue G-250 method [60,61]. Samples were taken during the same growth period and from the same leaf positions.

\subsection{Extraction and Quantification of Proteins}

The leaves of all samples were frozen in liquid nitrogen and ground with a pestle and mortar. TCA/acetone (1:9) was added to the powder $(1: 5, v / v)$ and mixed by vortex. The mixture was placed at $-20{ }^{\circ} \mathrm{C}$ for $4 \mathrm{~h}$, and centrifuged at $6000 \times \mathrm{g}$ for $40 \mathrm{~min}$ at $4{ }^{\circ} \mathrm{C}$. The supernatant was discarded. The pre-cooling acetone was added into the pellet and washed three times. The precipitation was air dried. SDT buffer $(1: 30, v / v)$ was added to $20-30 \mathrm{mg}$ of powder, mixed, and boiled for $5 \mathrm{~min}$. The supernatant was filtered with $0.22 \mu \mathrm{m}$ filters. The filtrate was quantified with the BCA Protein Assay Kit (P0012, Beyotime, Shanghai, China).

\subsection{FASP Digestion}

Proteins of each sample (200 $\mu \mathrm{g})$ were mixed with $200 \mu \mathrm{L}$ UA buffer, and the mixture was filtered by a ultrafiltration centrifugal tube $(10 \mathrm{kD})$ at $14,000 \times \mathrm{g}$ for $15 \mathrm{~min}$, and the pellet was re-suspended and filtered. The $100 \mu \mathrm{L}$ iodoacetamide (100 mM IAA in UA buffer) was added into each sample and incubated for $30 \mathrm{~min}$ in darkness. The filters were washed with $100 \mu \mathrm{L}$ UA buffer three times and subsequently with $100 \mu \mathrm{L} 25 \mathrm{mM} \mathrm{NH}_{4} \mathrm{HCO}_{3}$ buffer twice. The protein suspensions were digested with $4 \mu \mathrm{g}$ trypsin in $40 \mu \mathrm{L} 25 \mathrm{mM} \mathrm{NH}_{4} \mathrm{HCO}_{3}$ buffer overnight at $37^{\circ} \mathrm{C}$. The collection of the resulting peptides with a new collector and peptides were desalted on C18 Cartridges, freeze-dried, and reconstituted in $40 \mu \mathrm{L}$ of $0.1 \%(v / v)$ formic acid. The peptide content was estimated by UV light spectral density at $280 \mathrm{~nm}$.

\subsection{LC-MS/MS Analysis}

Proteins were separated by using an Easy nLC HPLC liquid phase system with an increasing flow rate. The chromatographic column was balanced by $95 \%$ A solution $(0.1 \%$ formic acid aqueous solution). The sample was injected onto the C18 column (Thermo Scientific Acclaim PepMap100, $100 \mu \mathrm{m} \times 2 \mathrm{~cm}$, nanoViper C18) by an automatic sample injector and separated by C18-a2 analytical column (Thermo scientific EASY column, $10 \mathrm{~cm}$, ID75 $\mu \mathrm{m}, 3 \mu \mathrm{m}, \mathrm{C} 18-\mathrm{A}$ ) at a flow rate of $300 \mathrm{~mL} / \mathrm{min}$. Solution B ( $0.1 \%$ formic acid acetonitrile aqueous solution) was then used for gradient elution. 
The samples separated by chromatography were analyzed with a Q-Exactive mass spectrometer. The analysis time was $120 \mathrm{~min}$, the detection method was the positive-ion mode, the parent-ion scanning range was $300-1800 \mathrm{~m} / z$, the resolution of a first-order mass spectrometer was 70,000 at $200 \mathrm{~m} / z$, the AGC target was 3e6, the first level maximum IT was $10 \mathrm{~ms}$, the number of scan ranges was 1 , and the dynamic exclusion was $40.0 \mathrm{~s}$.

\subsection{Database Search and Protein Quantification}

The database used was P16440_Unigene.fasta.transdecoder_73797_20161212.fasta (Sequence 73797, self-building). Maxquant software 1.3.0.5 [62] was used to analyze the protein qualitatively and quantitatively in the original raw file. The maxquant software parameter table is shown in Table 3.

Table 3. Maxquant software parameter table.

\begin{tabular}{cc}
\hline Item & Value \\
\hline Main search ppm & 6 \\
Missed cleavage & 2 \\
MS/MS tolerance ppm & 20 \\
De-Isotopic & True \\
Enzyme & Trypsin \\
Database & P16440_Unigene.fasta.transdecoder_73797_20161212.fasta \\
Fixed modification & Carbamidomethyl (C) \\
Variable modification & Oxidation(M), Acetyl (Protein N-term) \\
Decoy database pattern & reverse \\
LFQ & True \\
LFQ min. ratio count & 1 \\
Match between runs & 2 min \\
Peptide FDR & 0.01 \\
Protein FDR & 0.01 \\
\hline
\end{tabular}

For the proteins identified by mass spectrometry in the original data, differentially expressed proteins and differentially expressed proteins were screened by the screening criteria of Ratio $>+/-2$ and $p$ value $<0.05$. The quantified protein sequence information was extracted in batches from the UniProtKB database (version number: 201701).

\subsection{Protein GO Functional Annotation and KEGG Pathway Annotation}

Blast $2 \mathrm{GO}$ was used to annotate the functions of the targeted proteins [63]. KASS software was used for pathway analysis. The target protein sequences were classified by KO compared to the KEGG GENES database, and then the pathway information involved in the target protein sequence was automatically acquired according to the $\mathrm{KO}$ classification.

\subsection{Protein-Protein Interact Network (PPI)}

The protein - protein interaction information of the studied proteins was retrieved from the IntAct molecular interaction database (http:/ / www.ebi.ac.uk/intact/) by their gene symbols or STRING software (http:/ / string-db.org/). The results were downloaded in the XGMML format and imported into Cytoscape5 software (http:/ / www.cytoscape.org/, version 3.2.1) to visualize and further analyze the functional protein-protein interaction networks. Furthermore, the degree of each protein was calculated to evaluate the importance of the protein in the PPI network. 


\section{Conclusions}

E. angustifolia seedlings' growth was significantly inhibited by salt stress, and growth was improved in mycorrhizal symbionts. Furthermore, mycorrhizal E. angustifolia had a higher leaf soluble sugar and soluble protein content than that of the non-mycorrhizal seedlings during salt stress. Additionally, it was found that AMF inoculated E. angustifolia seedlings increased secondary metabolism, enhanced $\mathrm{Ca}^{2+}$ signal transduction and ROS scavenging capacity, promoted protein biosynthesis, accelerated protein folding, and inhibited protein degradation compared with non-inoculated plants under salt stress. In addition, AMF maintained the conformation stability of the PS II reaction center, accelerated the photosynthetic electron transfer, enhanced ATP synthesis, and provided sufficient energy for cell activity. Overall, these findings show that AMF played an important role in easing salt stress in plants and contributed to saline alkali soil remediation.

Author Contributions: T.J. and J.W. contributed equally for this article. T.J. and J.W. did the experiment and analyzed data and wrote this paper. W.C. participated to analyze the data. X.F. and X.S. participated to do this experiment. F.S. designed this experiment. All authors read and approved the final manuscript.

Funding: This research was funded by the National Nature Science Foundation of China (No. 31570635), the Special Fund for Forest Scientific Research in the Public Welfare, (No. 201504409), Heilongjiang Natural Fund Team Project: Study on Microbial Control Technology of Agricultural Non-point Source Pollution in Cold Region, 100 Discipline Young Scholars Project of the Heilongjiang University.

Acknowledgments: We thank Shanghai Applied Protein Technology Co. Ltd. for the help with Label-free sequencing. This work was supported by Key Laboratory of Microbiology, College of Heilongjiang Province.

Conflicts of Interest: The authors declare no conflict of interest. 


\section{Appendix A}

Table A1. The identification and quantitative analysis of the protein in leaves of E. angustifolia with AMF under salt stress (salt-tolerance-related proteins induced by symbiosis).

\begin{tabular}{|c|c|c|c|c|c|c|c|c|}
\hline TR Number & Protein Name & $\begin{array}{l}\text { Unique } \\
\text { Peptides }\end{array}$ & $\begin{array}{c}\text { Sequence } \\
\text { Coverage [\%] }\end{array}$ & $\begin{array}{l}\text { Mol. Weight } \\
{[\mathrm{kDa}]}\end{array}$ & $\mathrm{AM} / \mathrm{CK}$ & $\mathrm{AM}+\mathrm{NaCl} / \mathrm{AM}$ & $\begin{array}{c}\text { Fold } \\
\text { Change }\end{array}$ & $\begin{array}{c}t \text { Test } p \\
\text { Value }\end{array}$ \\
\hline \multicolumn{9}{|l|}{ Metabolic process } \\
\hline 115007 & Auxin response 4 & 2 & 5.7 & 52.521 & under & over & & \\
\hline 142773 & purple acid phosphatase 2-like [64,65] & 2 & 11.2 & 53.569 & under & over & & \\
\hline 71893 & probable alkaline neutral invertase B [22] & 2 & 4 & 65.249 & under & over & & \\
\hline \multicolumn{9}{|c|}{ Protein folding and degradation } \\
\hline 101573 & AAA-ATPase At5g17760-like [66] & 2 & 8 & 58.706 & under & over & & \\
\hline 12335 & Heat shock 70 kDa partial [67] & 1 & 55.3 & 22.844 & under & over & & \\
\hline 143526 & small heat shock protein $17.3 \mathrm{kDa}$ & 2 & 1.1 & 81.397 & over & over & 2.32 & 0.032 \\
\hline \multicolumn{9}{|l|}{ Protein synthesis } \\
\hline 109446 & ubiquitin-60S ribosomal L40 [23] & 1 & 41.4 & 14.643 & under & over & & \\
\hline \multicolumn{9}{|l|}{ Redox } \\
\hline 127397 & thioredoxin $1[68,69]$ & 1 & 10.5 & 20.973 & under & over & & \\
\hline 130845 & glutaredoxin 3 [37] & 2 & 24 & 13.046 & under & over & & \\
\hline \multicolumn{9}{|l|}{ Cytoskeleton } \\
\hline 114464 & actin-related 7 [70] & 1 & 4.7 & 39.154 & under & over & & \\
\hline \multicolumn{9}{|l|}{ Transport } \\
\hline 119356 & transmembrane $147[71]$ & 2 & 10.5 & 25.299 & under & over & & \\
\hline 88151 & vesicle transport v-SNARE 13 [72] & 2 & 15.8 & 24.96 & under & over & & \\
\hline \multicolumn{9}{|l|}{ Signalling } \\
\hline 136541 & serine/threonine-protein kinase PRP4 $[73,74]$ & 1 & 5.1 & 28.709 & under & over & & \\
\hline
\end{tabular}


Table A2. The identification and quantitative analysis of the protein in leaves of E. angustifolia with AMF under salt stress (salt-induced mycorrhizal protein).

\begin{tabular}{|c|c|c|c|c|c|c|c|}
\hline TR Number & Protein Name & $\begin{array}{l}\text { Unique } \\
\text { Peptides }\end{array}$ & $\begin{array}{c}\text { Sequence } \\
\text { Coverage }[\%]\end{array}$ & $\begin{array}{l}\text { Mol. Weight } \\
{[\mathrm{kDa}]}\end{array}$ & $\mathrm{AM}+\mathrm{NaCl} / \mathrm{AM}$ & $\begin{array}{l}\text { Fold } \\
\text { Change }\end{array}$ & $\begin{array}{l}t \text { Test } p \\
\text { Value }\end{array}$ \\
\hline \multicolumn{8}{|l|}{ Metabolic process } \\
\hline 103310 & beta-glucosidase 40 [75] & 3 & 7.7 & 60.254 & over & & \\
\hline 142616 & beta-glucosidase $42[75]$ & 7 & 18.8 & 57.009 & over & 2.16 & 0.037 \\
\hline 105849 & 1,2-dihydroxy-3-keto-5-methylthiopentene dioxygenase [76] & 6 & 32.2 & 23.919 & over & 2.42 & 0.014 \\
\hline 121954 & anthocyanidin reductase [77] & 2 & 5.2 & 37.122 & over & & \\
\hline 123153 & shikimate O-hydroxycinnamoyltransferase-like & 2 & 5.5 & 47.978 & over & & \\
\hline 124556 & acetyl-CoA carboxylase [78] & 5 & 4.8 & 155.54 & over & & \\
\hline 47457 & chorismate mutase chloroplastic-like $[20,21]$ & 1 & 8.7 & 14.428 & over & & \\
\hline 66089 & probable cinnamyl alcohol dehydrogenase $1[20,21]$ & 9 & 31.5 & 38.574 & over & 2.22 & 0.006 \\
\hline 99076 & caffeoyl-CoA O-methyltransferase $[20,21]$ & 1 & 1.5 & 72.473 & over & & \\
\hline 73516 & phosphoglucan phosphatase chloroplastic isoform X1 & 1 & 2 & 62.123 & over & & \\
\hline 98093 & $\begin{array}{l}\text { delta-1-pyrroline-5-carboxylate dehydrogenase } \\
\text { mitochondrial-like [2] }\end{array}$ & 9 & 35.5 & 37.633 & over & 2.07 & 0.001 \\
\hline 99156 & anthranilate phosphoribosyltransferase $[20,21]$ & 2 & 3.3 & 83.928 & over & 2.06 & 0.016 \\
\hline 120341 & UDP-glucose 4-epimerase [79] & 15 & 49.7 & 43.428 & over & 2.68 & 0.007 \\
\hline \multicolumn{8}{|l|}{ Signalling } \\
\hline 87721 & phospholipase C & 6 & 14 & 59.562 & over & & \\
\hline 114971 & calcium-dependent kinase $29[30]$ & 1 & 6 & 51.414 & over & & \\
\hline 142143 & calcium-transporting ATPase plasma membrane-type [28] & 1 & 11.4 & 15.308 & over & & \\
\hline 155255 & glycine-rich 2-like [80] & 2 & 32.8 & 11.363 & over & 2.17 & 0.018 \\
\hline 19556 & calcium-transporting ATPase plasma membrane-type [28] & 1 & 8.8 & 18.439 & over & & \\
\hline 67342 & probable calcium-binding CML20 [29] & 3 & 15.8 & 22.997 & over & & \\
\hline 61926 & calmodulin-7 [30] & 7 & 46.7 & 21.009 & over & 2.7 & 0.046 \\
\hline 24540 & guanylate-binding family & 1 & 7.8 & 13.089 & over & & \\
\hline \multicolumn{8}{|c|}{ Protein folding and degradation } \\
\hline 110214 & E3 ubiquitin- ligase UPL3 [26] & 2 & 2.3 & 196.04 & over & & \\
\hline 122927 & peptidyl-prolyl cis-trans isomerase FKBP12 [23,25] & 2 & 21.4 & 12.076 & over & & \\
\hline 74495 & $\begin{array}{l}\text { FKBP-type peptidyl-prolyl cis-trans isomerase } 5 \text { isoform } 1 \\
{[23,25]}\end{array}$ & 1 & 8.9 & 33.514 & over & & \\
\hline 61488 & prefoldin subunit $2[23,25]$ & 3 & 31.1 & 16.223 & over & & \\
\hline 72620 & prefoldin subunit $1[23,25]$ & 3 & 26.4 & 14.922 & over & & \\
\hline 91034 & peptidyl-prolyl cis-trans isomerase CYP18-1 [23,25] & 1 & 8.8 & 17.474 & over & & \\
\hline 93048 & peptidyl-prolyl cis-trans isomerase FKBP62-like $[23,25]$ & 1 & 20.8 & 13.805 & over & & \\
\hline 73875 & ubiquitin-like 1-activating enzyme E1 B [26] & 6 & 11.4 & 74.427 & over & 2.64 & 0.000 \\
\hline \multicolumn{8}{|l|}{ Protein synthesis } \\
\hline 92755 & $60 S$ acidic ribosomal P1 & 2 & 36.9 & 14.968 & over & 2.73 & 0.013 \\
\hline 33127 & exportin-2 [81] & 1 & 14.1 & 11.097 & over & & \\
\hline
\end{tabular}


Table A2. Cont.

\begin{tabular}{|c|c|c|c|c|c|c|c|}
\hline TR Number & Protein Name & $\begin{array}{l}\text { Unique } \\
\text { Peptides }\end{array}$ & $\begin{array}{c}\text { Sequence } \\
\text { Coverage }[\%]\end{array}$ & $\begin{array}{l}\text { Mol. Weight } \\
{[\mathrm{kDa}]}\end{array}$ & $\mathrm{AM}+\mathrm{NaCl} / \mathrm{AM}$ & $\begin{array}{l}\text { Fold } \\
\text { Change }\end{array}$ & $\begin{array}{l}t \text { Test } p \\
\text { Value }\end{array}$ \\
\hline 106351 & nuclear pore complex NUP98A $[82,83]$ & 1 & 3.8 & 50.09 & over & & \\
\hline 109126 & elongation factor mitochondrial [24] & 2 & 5.4 & 44.427 & over & & \\
\hline \multicolumn{8}{|l|}{ Redox } \\
\hline 101431 & monothiol glutaredoxin-mitochondrial & 3 & 15.6 & 19.243 & over & 2.27 & 0.010 \\
\hline 12964 & peroxidase 16 -like & 1 & 7.6 & 13.952 & over & & \\
\hline 29124 & probable linoleate 9S-lipoxygenase 5 & 2 & 19.3 & 17.097 & over & 3.06 & 0.036 \\
\hline 59386 & glutathione S-transferase L3-like $[39,40]$ & 11 & 42.6 & 29.735 & over & 2.65 & 0.003 \\
\hline 79685 & probable glutathione peroxidase $2[45,46]$ & 6 & 33.2 & 21.733 & over & 2.35 & 0.017 \\
\hline 97566 & 2,4-D inducible glutathione S-transferase $[39,40]$ & 4 & 22.7 & 25.559 & over & & \\
\hline 87674 & glutathione S-transferase T1 $[39,40]$ & 3 & 16.8 & 27.036 & over & & \\
\hline 88089 & probable glutathione peroxidase $8[45,46]$ & 3 & 17 & 19.394 & over & 2.43 & 0.006 \\
\hline \multicolumn{8}{|c|}{ 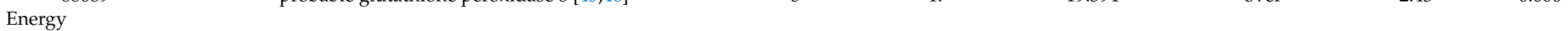 } \\
\hline 109215 & ATP synthase subunit mitochondrial & 4 & 60.6 & 14.69 & over & 3.36 & 0.015 \\
\hline 141440 & $\begin{array}{c}\text { NADH dehydrogenase [ubiquinone] } 1 \text { beta subcomplex } \\
\text { subunit } 7\end{array}$ & 5 & 40.6 & 15.264 & over & 2.59 & 0.010 \\
\hline 28754 & $\begin{array}{c}\text { NADH dehydrogenase [ubiquinone] } 1 \text { beta subcomplex } \\
\text { subunit } 7\end{array}$ & 1 & 7.9 & 11.862 & over & & \\
\hline 78587 & NADH dehydrogenase [ubiquinone] iron-sulfur mitochondrial & 2 & 9.4 & 18.933 & over & 2.19 & 0.029 \\
\hline 104876 & cytochrome c oxidase subunit mitochondrial-like & 2 & 30.3 & 11.185 & over & 2.27 & 0.050 \\
\hline \multicolumn{8}{|c|}{ g } \\
\hline 88283 & aquaporin PIP2-1-like [84] & 1 & 4.9 & 30.753 & over & & \\
\hline 7488 & aquaporin PIP1-4 [84] & 2 & 11.9 & 21.091 & over & & \\
\hline 87290 & mechanosensitive ion channel 1 [85] & 2 & 2.5 & 85.926 & over & & \\
\hline 88244 & vacuolar sorting-associated 2 homolog 1 [86] & 2 & 6.7 & 25.106 & over & & \\
\hline \multicolumn{8}{|c|}{ 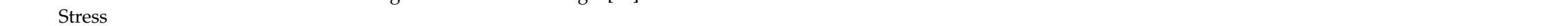 } \\
\hline 109624 & GDSL esterase lipase 1 [87] & 3 & 13.2 & 42.914 & over & & \\
\hline 93161 & GDSL esterase lipase At3g27950-like [88] & 2 & 8.9 & 30.265 & over & 2.07 & 0.029 \\
\hline 58645 & stress response NST1-like & 1 & 2.8 & 35.36 & over & & \\
\hline \multicolumn{8}{|l|}{ Photosynthesis } \\
\hline 71168 & $\begin{array}{c}\text { photosystem II D1 precursor processing } \\
\text { PSB27-chloroplastic-like [54-56] }\end{array}$ & 2 & 12.3 & 23.507 & over & & \\
\hline 8490 & hexokinase-3 isoform X1 [89] & 1 & 14.9 & 16.704 & over & 2.5 & 0.002 \\
\hline \multicolumn{8}{|l|}{ Cytoskeleton } \\
\hline 73217 & profilin & 2 & 13.1 & 19.413 & over & 2.45 & 0.039 \\
\hline 121711 & actin-depolymerizing factor 1 [90] & 2 & 26.6 & 16.042 & over & & \\
\hline
\end{tabular}




\section{References}

1. Sun, Y.F.; Song, F.Q.; Chang, W.; Fan, X.X. The effects of the AMF on the growth and physiology of the E. angustifolia seedlings under the stress of saline. Sci. Silvae Sin. 2016, 52, 18-27.

2. Porcel, R.; Aroca, R.; Ruiz-Lozano, J.M. Salinity stress alleviation using arbuscular mycorrhizal fungi. Agron. Sustain. Dev. 2012, 32, 181-200. [CrossRef]

3. Kapoor, R.; Evelin, H.; Mathur, P.; Giri, B. Plant Acclimation to Environmental Stress; Springer: New York, NY, USA, 2012; pp. 359-401.

4. Li, X.L.; Feng, G. Arbuscular Mycorrhizal Ecological Physiology; Sino-Culture Press: Beijing, China, 2001.

5. Guo, X.Z.; Bi, G.C. Mycorrhiza and Its Application Technology; China Forestry Publishing House: Beijing, China, 1989.

6. Li, G.Z.; Chen, Z.C.; Li, X.C.; Sheng, J.D.; Huang, C.F.; Jin, J.X. Spatial distribution of arbuscular mycorrhizal fungi in the roots of Phragmites australis in Xinjiang. Pr. Sci. 2016, 33, 1267-1274.

7. Ruiz-Lozano, J.M.; Porcel, R.; Azcon, C.; Aroca, R. Regulationby arbuscular mycorrhizae of the integrated physiological responseto salinity in plants: New challenges in physiological andmolecular studies. J. Exp. Bot. 2012, 5, 1-12.

8. Kumar, A.; Sharma, S.; Mishra, S. Influence ofarbuscularmycorrhizal (AM) fungi and salinity on seedling growth, soluteaccumulation, and mycorrhizal dependency of Jatrophacurcas L. J. Plant Growth Regul. 2010, 29, 297-306. [CrossRef]

9. Li, M.N.; Zhang, K.; Long, G.; Sun, Y.; Kang, J.M.; Zhang, T.J.; Cao, S.H. iTRAQ-based comparative proteomic analysis reveals tissue-specific and novel early-stage molecular mechanisms of salt stress response in Carex rigescens. Environ. Exp. Bot. 2017, 143, 99-114. [CrossRef]

10. Ma, Q.L.; Kang, J.M.; Long, R.C.; Cui, Y.G.; Zhang, T.J.; Xiong, J.B.; Yang, Q.C.; Sun, Y. Proteomic analysis of salt and osmotic-drought stress in alfalfaseedlings. J. Integr. Agric. 2016, 15, 2266-2278. [CrossRef]

11. Yu, J.J.; Chen, S.X.; Dai, S.J. Physiological and proteomic analysis of salinity tolerance in Puccinellia tenuiflora. J. Proteome Res. 2011, 10, 3852-3870. [CrossRef] [PubMed]

12. Banaei-Asl, F.; Farajzadeh, D.; Bandehagh, A.; Komatsu, S. Comprehensive proteomic analysis of canola leaf inoculated with a plant growth-promoting bacterium, Pseudomonas fluorescens, under salt stress. Biochim. Biophys. Acta 2016, 1864, 1222-1236. [CrossRef] [PubMed]

13. Yin, Y.Q.; Yang, R.Q.; Han, Y.B.; Gu, Z.X. Comparative proteomic and physiological analysesreveal the protective effect of exogenous calcium on the germinating soybean response to salt stress. J. Proteom. 2015, 113, 110-126. [CrossRef] [PubMed]

14. Niu, X.P.; Xu, J.T.; Chen, T.; Tao, A.; Qi, J.M. Proteomic changes in kenaf (Hibiscus cannabinus L.) leaves under saltstress. Ind. Crop. Prod. 2016, 91, 255-263. [CrossRef]

15. Lv, D.W.; Zhu, G.R.; Zhu, D.; Bian, Y.W.; Liang, X.N.; Cheng, Z.W.; Deng, X.; Yan, Y.M. Proteomic and phosphoproteomic analysis reveals the response and defense mechanism in leaves of diploid wheat T. monococcum under salts tress and recovery. J. Proteom. 2016, 143, 93-105. [CrossRef] [PubMed]

16. Morandi, D. Occurrence of Phytoalexins and Phenolic com Pounds in endomyeorrhizalinteractions, and their Potential role in biological control. Plant Soil 1996, 185, 241-251. [CrossRef]

17. Akiyama, K.; Matsuoka, H.; Hayashi, H. Isolation and identification of a phosphate deficieney-induced C-glycosylflavonoid that stimulates arbuscular mycorrhiza formation in melon roots. Mol. Plant-Microbe Interact. 2002, 15, 334-340. [CrossRef] [PubMed]

18. Zhao, X.; Yan, X.F. Effects of arbuscular mycorrhizal fungi on plant secondary metabolism. Chin. J. Plant Ecol. 2006, 30, 514-521.

19. Larose, G.; Chnevert, R.; Moutoglis, P.; Gagne, S.; Piche, Y.; Vietheilig, H. Flavonoid Ievels in roots of Medicagosativa are modulated by the developmental stage of the symbiosis and the root colonizing arbuseular mycorrhizal fungus. J. Plant Physiol. 2002, 159, 1329-1339. [CrossRef]

20. Qian, X.; Yu, K.J.; Yuan, G.S.; Yang, H.Y.; Pan, Q.H.; Zhu, B.Q. Research progress in plant anthranilate synthase. J. Trop. Biol. 2015, 6, 504-511.

21. Pérez, E.; Rubio, M.B.; Cardoza, R.E.; Gutiérrez, S.; Bettiol, W.; Monte, E.; Hermosa, R. The importance of chorismate mutase in the biocontrol potential of Trichoderma parareesei. Front. Microbiol. 2015, 6, 1181. [CrossRef] 
22. Niu, J.Q.; Wang, A.Q.; Huang, J.L.; Yang, L.T.; Li, Y.R. Cloning and expression analysis of sugarcane alkaline/neutral invertase gene SoNIN1. Acta Agron. Sin. 2014, 40, 253-263. [CrossRef]

23. Li, H.Y.; Yu, P.; Zhang, Y.X.; Wu, C.; Ma, C.Q.; Yu, B.; Zhu, N.; Koh, J.; Chen, S.X. Salt stress response of membrane proteome of sugarbeet monosomic addition line M14. J. Proteom. 2015, 127, 18-33. [CrossRef]

24. Suzuki, H.; Ueda, T.; Taguchi, H.; Takeuchi, N. Chaperoneproperties of mammalian mitochondrial translation elongationfactor Tu. J. Biol. Chem. 2007, 282, 4076-4084. [CrossRef] [PubMed]

25. Yu, J.J.; Chen, S.X.; Dai, S.J. Comparative proteomic analysis of Puccinellia tenuiflora leaves under $\mathrm{Na}_{2} \mathrm{CO}_{3}$ stress. Int. J. Mol. Sci. 2013, 14, 1740-1762. [CrossRef] [PubMed]

26. Lyzenga, W.J.; Stone, S.L. Abiotic stress tolerance mediated by protein ubiquitination. J. Exp. Botary 2012, 63, 599-616. [CrossRef] [PubMed]

27. Chen, S.S.; Lan, H.Y. Signal Transduction Pathways in Response to Salt Stress in Plants. Plant Physiol. J. 2011, 47, 119-128.

28. Kim, J.S.; Park, S.J.; Kwak, K.J.; Kim, Y.O.; Kim, J.K.; Song, J.; Jang, B.; Jung, S.H.; Kang, H. Cold shock domain proteins and glycine-rich RNA-binding proteins from Arabidopsis thaliana can promote the cold adaptation process in Escherichia coli. Nucleic Acids Res. 2007, 35, 505-516. [CrossRef]

29. Harmon, A.C. Calcium-regulated protein kinases of plants. Gravit. Space Biol. Bull. 2003, 16, 83-90. [PubMed]

30. Asano, T.; Hayashi, N.; Kikuchi, S.; Ohsugi, R. CDPK-mediated abiotic stress signaling. Plant Signal. Behav. 2012, 7, 817-821. [CrossRef] [PubMed]

31. Choudhury, S.; Panda, P.; Sahoo, L.; Panda, S.K. Reactive oxygen species signalingin plants under abiotic stress. Plant Signal. Behav. 2013, 8, e23681. [CrossRef]

32. Wang, L.X.; Pan, D.Z.; Li, J.; Tan, F.L.; Benning, S.H.; Liang, W.Y.; Chen, W. Proteomic analysis of changes in the Kandelia candel chloroplast proteins reveals pathways associated with salt tolerance. Plant Sci. 2015, 231, 159-172. [CrossRef] [PubMed]

33. Rouhier, N.; Gelhaye, E.; Jacquot, J.P. Redox control by dithiol-disulfide exchange in plants: II. The cytosolic and mitochondrial systems. Ann. N. Y. Acad. Sci. 2002, 973, 520-528. [CrossRef] [PubMed]

34. Scheibe, R.; Dietz, K.J. Reduction-oxidation network for flexible adjustment ofcellular metabolism in photoautotrophic cells. Plant Cell Environ. 2012, 35, 202-216. [CrossRef] [PubMed]

35. Jacquot, J.P.; Rouhier, N.; Gelhaye, E. Redox control by dithiol-disulfide exchange in plants: I. The chloroplastic systems. Ann. N. Y. Acad. Sci. 2002, 973, 508-519. [CrossRef] [PubMed]

36. Michelet, L.; Zaffagnini, M.; Morisse, S.; Sparla, F.; Pérez-Pérez, M.E.; Francia, F.; Danon, A.; Marchand, C.H.; Fermani, S.; Trost, P.; et al. Redox regulation of the Calvin-Benson cycle: Something old, something new. Front. Plant Sci. 2013, 4, 470. [CrossRef] [PubMed]

37. Guo, Y.; Huang, C.; Xie, Y.; Song, F.; Zhou, X. A tomato glutaredoxin gene SLGRX1 regulates plant responses to oxidative, drought and salt stresses. Planta 2010, 232, 1499-1509. [CrossRef] [PubMed]

38. Song, C.Q.; Miao, H.F.; Zhu, B. The role of plant glutathione-S-transferase in phytoremediation. Anhui Agric. Bull. 2010, 16, 1007-7731.

39. Mittler, R. Oxidative stress, antioxidants and stress tolerance. Trends Plant Sci. 2002, 7, 405-410. [CrossRef]

40. Margis, R.; Dunand, C.; Teixeira, F.K.; Pinheiro, M.M. Glutathione peroxidase family-an evolutionary overview. FEBS J. 2008, 275, 3959-3970. [CrossRef] [PubMed]

41. Sun, G.R.; Wang, J.B.; Cao, W.Z.; Du, K.; Zhang, B. GST activity and its related indexes in the Chloroplasts of Puccinellia tenuiflora seedlings under $\mathrm{Na}_{2} \mathrm{CO}_{3}$ stress. Northwest Bot. Gaz. 2005, 25, 2495-2501.

42. Avsian, K.O.; Gueta, D.Y.; Ben, H.G.; Eshdat, Y. Regulation of stress-induced phospholipid hydroperoxide glutathione peroxidase expression in citrus. Planta 1999, 4, 469-477. [CrossRef]

43. Beeor-Tzahar, T.; Ben-Hayyim, G.; Holland, D.; Faltun, Z.; Eshdat, Y. A stress-associated citrus protein is a distinct plant phospholipid hydroperoxide glutathione peroxidase. FEBS Lett. 1995, 366, 151-155. [CrossRef]

44. Kim, Y.J.; Jang, M.G.; Noh, H.Y.; Lee, H.J.; Sukweenadhi, J.; Kim, J.H.; Kim, S.Y.; Kwon, W.S.; Yang, D.C. Molecular characterization of two glutathione peroxidase genes of Panax ginseng and their expression analysis against environmental stresses. Gene 2014, 1, 33-41. [CrossRef] [PubMed]

45. Roxas, V.P.; Smith, R.K., Jr.; Allen, E.R.; Allen, R.D. Overexpression of glutathione S-transferase/glutathione peroxidase enhances growth of transgenic tobacco seedlings during stress. Nat. Biotechnol. 1997, 15, 988-991. [CrossRef] [PubMed] 
46. Roxas, V.P.; Lodhi, S.A.; Garrett, D.K.; Mahan, J.R.; Allen, R.D. Stress Tolerance in Transgenic Tobacco Seedlings that Overexpress Glutathione S-Transferase/Glutathione Peroxidase. Plant Cell Physiol. 2000, 41, 1229-1234. [CrossRef] [PubMed]

47. Chang, W.; Sui, X.; Fan, X.X.; Jia, T.T. Arbuscular Mycorrhizal Symbiosis Modulates Antioxidant Response and Ion Distribution in Salt-Stressed Elaeagnus angustifolia Seedlings. Front. Microbiol. 2018, 9, 652. [CrossRef] [PubMed]

48. Talaat, N.B.; Shawky, B.T. Protective effects of arbuscular mycorrhizal fungi on wheat (Triticum aestivum L.) plants exposed to salinity. Environ. Exp. Bot. 2014, 98, 20-31. [CrossRef]

49. Yue, Y.N. Effects of Arbuscular Mycorrhizal Fungi on Plant Salt Tolerance in Songnen Saline Grassland; Northeast Forestry University: Haerbin, China, 2015.

50. Sheng, M.; Tang, M.; Chen, H.; Yang, B.W.; Zhang, F.F.; Huang, Y.H. Influence of arbuscular mycorrhizae on photosynthesis and water status of maize plants under salt stress. Mycorrhiza 2008, 18, 287-296. [CrossRef] [PubMed]

51. Lin, J.X.; Wang, Y.N.; Sun, S.N.; Mu, C.S.; Yan, X.F. Effects of arbuscular mycorrhizal fungi on the growth, photosynthesis and photosynthetic pigments of Leymus chinensis seedlings under salt-alkali stress and nitrogen deposition. Sci. Total Environ. 2017, 576, 234-241. [CrossRef]

52. Liu, H.G. AMF to Improve the Mechanism of Salt Resistance of Lycium barbarum L.; Northwest A \& F University: Yangling, China, 2016.

53. Tang, J. Effects of Mycorrhizal Fungi (AMF) on Salinity Tolerance in the Cultivation of Healthy Vegetables; Sichuan Agricultural University: Yaan, China, 2016.

54. Järvi, S.; Suorsa, M.; Aro, E.M. Photosystem II repair in plant chloroplasts-Regulation, assisting proteins and shared components with photosystem II biogenesis. Biochim. Biophys. Acta 2015, 1847, 900-909. [CrossRef] [PubMed]

55. Greenberg, B.M.; Gaba, V.; Canaani, O.; Malkin, S.; Mattoo, A.K.; Edelman, M. Separate photosensitizers mediate degradation of the $32 \mathrm{kDa}$ photosystem II reaction center protein in the visible and UV spectral regions. Proc. Natl. Acad. Sci. USA 1989, 86, 6617-6620. [CrossRef]

56. Zhu, S.Q.; Xia, S.L.; Chen, Q. Advances in the regulation mechanism of photosystem IID1 protein expression. Guizhou Agric. Sci. 2012, 40, 37-42.

57. Guo, X. Role of Glutathione GRX in Response to Temperature Stress in Tomato. Master's Thesis, Zhejiang University, Hangzhou, China, 2016.

58. Jia, T.T.; Chang, W.; Fan, X.X. Effects of Arbuscular mycorrhizal fungi on photosynthetic and chlorophyll fluorescence characteristics in Elaeagnus angustifolia seedlings under salt stress. Acta Ecol. Sin. 2018, 38, 1337-1347.

59. Phillips, J.M.; Hayman, D.S. Improved procedures for clearing roots and staining parasitic and vesicular-arbuscular mycorrhizal fungi for rapid assessment of infection. Trans. Br. Mycol. Soc. 1970, 55, 158-161. [CrossRef]

60. Wang, X.K.; Huang, S.L. Plant Physiological and Biochemical Experimental Principles and Technology, 3rd ed.; Higher Education Press: Beijing, China, 2015.

61. Zhang, Z.L.; Qu, W.J. Plant Physiology Experimental Guide, 3rd ed.; Higher Education Press: Beijing, China, 2003.

62. Wisniewski, J.R.; Zougman, A.; Nagaraj, N.; Mann, M. Universal sample preparation method for proteome analysis. Nat. Methods 2009, 6, 359-362. [CrossRef] [PubMed]

63. Cox, J.; Mann, M. MaxQuant enables high peptide identification rates, individualized p.p.b.-range mass accuracies and proteome-wide protein quantification. Nat. Biotechnol. 2008, 6, 1367-1372. [CrossRef] [PubMed]

64. Del Pozo, J.C.; Allona, I.; Rubio, V.; Leyva, A.; de la Peña, A.; Aragoncillo, C.; Paz-Ares, J. A type 5 acid phosphatase gene from Arabidopsis thaliana is induced by phosphate starvation and by some other types of phosphate mobilising/oxidativestress conditions. Plant J. 1999, 19, 579-589. [CrossRef] [PubMed]

65. Li, W.Y.; Shao, G.; Lam, H. Ectopic expression of GmPAP3 alleviates oxidative damage caused by salinity and osmotic stresses. New Phytol. 2008, 178, 80-91. [CrossRef] [PubMed]

66. Monroe, N.; Hill, C.P. Meiotic Clade AAA ATPases: Protein Polymer Disassembly Machines. J. Mol. Biol. 2016, 428 Pt B, 1897-1911. [CrossRef] 
67. Ren, Y.; Pan, H.; Yang, Y.; Pan, B.; Bu, W. Molecular cloning, characterization and functional analysis of a heat shock protein 70 gene in Cyclina sinensis. Fish Shellfish Immunol. 2016, 58, 663-668. [CrossRef]

68. Wong, J.H.; Cai, N.; Balmer, Y.; Tanaka, C.K.; Vensel, W.H.; Hurkman, W.J.; Buchanan, B.B. Thioredoxin targets of developing wheat seeds ide ntified by complementary proteomic approaches. Phytochemistry 2004, 65, 1629-1640. [CrossRef]

69. Traverso, J.A.; Vignols, F.; Cazalis, R.; Pulido, A.; Sahrawy, M.; Cejudo, F.J.; Meyer, Y.; Chueca, A. PsTRXh1 and PsTRXh2 Are Both Pea h-Type Thioredoxins with Antagonistic Behavior in Redox Imbalances. Plant Physiol. 2007, 143, 300. [CrossRef]

70. Wang, J.; Zhang, S.B.; Ma, D.; Ma, G.Y. Advances in Plant Actin Research. J. Anhui Agric. Sci. 2007, 35, 2860-2863.

71. Song, J.H.; Zhang, L.X. Progress on the transmembrane protein in plant. J. Biol. 2009, 26, 62-64.

72. Weber, T.; Parlati, F.; McNew, J.A.; Johnston, R.J.; Westermann, B.; Söllner, T.H.; Rothman, J.E. SNAREpins are functionally resistant to dis-ruption by NSF and $\alpha$ SNAP. J. Cell Biol. 2000, 149, 1063-1072. [CrossRef]

73. Sun, X.L.; Yu, Q.Y.; Tang, L.L.; Ji, W.; Bai, X.; Cai, H.; Liu, X.F.; Ding, X.D.; Zhu, Y.M. GsSRK, a G-type lectin S-receptor-like serine/threonine protein kinase, is apositive regulator of plant tolerance to salt stress. J. Plant Physiol. 2013, 170, 505-515. [CrossRef] [PubMed]

74. Ge, R.C.; Chen, G.P.; Zhao, B.C.; Shen, Y.Z.; Huang, Z.J. Cloning and functional characterization of a wheat serine/threoninekinase gene (TaSTK) related to salt-resistance. Plant Sci. 2007, 173, 55-60. [CrossRef]

75. Lee, K.H.; Piao, H.L.; Kim, H.Y.; Choi, S.M.; Jiang, F.; Hartung, W.; Hwang, I.; Kwak, J.M.; Lee, I.J.; Hwang, I. Activation of glucosidase via stress-induced polymerization rapidly increases active pools of abscisic acid. Cell 2006, 126, 1109-1120. [CrossRef]

76. Ge, C.; Wan, D.; Wang, Z.; Ding, Y.; Wang, Y.; Shang, Q.; Ma, F.; Luo, S. A proteomic analysis of rice seedlings responding to 1,2,4-trichlorobenzene stress. J. Environ. Sci. 2008, 20, 309-319. [CrossRef]

77. Luo, P.; Shen, Y.X.; Jin, S.J. Overexpression of Rosa rugosa anthocyanidin reductase enhances tobacco tolerance to abiotic stress through increased ROS scavenging and modulation of ABA signaling. Plant Sci. 2016, 245, 35-39. [CrossRef]

78. Lee, J.Q.; Zheng, S.X.; Yu, Z.N. Acetyl-CoA carboxylase: Advances in research on key enzymes of fatty acid metabolism and gene cloning. J. Appl. Environ. Biol. 2011, 17, 753-758.

79. Zhang, Q.; Hrmova, M.; Shirley, N.J.; Lahnstein, J.; Fincher, G.B. Gene expression patterns and catalytic properties of UDP-D-glucose4-epimerases from barley Hordeum vulgare L. Biochem. J. 2006, 394, 115-124. [CrossRef]

80. Singh, S.; Virdi, A.S.; Jaswal, R. A temperature-responsive gene in sorghum encodes a glycine-rich protein that interacts with calmodulin. Biochimie 2017, 137, 115-123. [CrossRef]

81. Gupta, A.; Kailasam, S.; Bansall, M. Insights into the Structural Dynamics of Nucleocytoplasmic Transport of tRNA by Exportin-t. Biophys. J. 2016, 110, 1264-1279. [CrossRef]

82. Kohler, A.; Hurt, E. Exporting RNA from the nucleus to the cytoplasm. Nat. Rev. Mol. Cell Biol. 2007, 8, 761-773. [CrossRef]

83. Mattaj, I.W.; Englmeier, L. Nucleocytoplasmic transport: The soluble phase. Annu. Rev. Biochem. 1998, 67, 265-306. [CrossRef]

84. Aroca, R.; Porcel, R.; Ruiz-Lozano, J.M. How does arbuscular mycorrhizal symbiosis regulate root hydraulic properties and plasma membrane aquaporins in Phaseolus vulgaris under drought, cold or salinity stresses? New Phytol. 2007, 73, 808-816. [CrossRef]

85. Geelen, D.; Leyman, B.; Batoko, H.; Di Sansebastiano, G.P.; Moore, I.; Blatt, M.R. The abscisic acid-related SNARE homolog NtSyr1contributes to secretion and growth: Evidence from competition with its cytosolic domain. Plant Cell 2002, 14, 387-406. [CrossRef]

86. Iqbal, M.S.; Siddiqui, A.A.; Alam, A.; Goyal, M.; Banerjee, C.; Sarkar, S.; Mazumder, S.; De, R.; Nag, S.; Saha, S.J.; et al. Expression, purification and characterization of Plasmodium falciparum vacuolar protein sorting 29. Protein Expr. Purif. 2016, 120, 7-15. [CrossRef]

87. Hong, J.K.; Choi, H.W.; Hwang, I.S.; Kim, D.S.; Kim, N.H.; Choi, D.S.; Kim, Y.J.; Hwang, B.K. Function of a novel GDSL-type pepper lipase gene, CaGLIP1, in disease sus-ceptibility and abiotic stress tolerance. Planta 2008, 227, 539-558. [CrossRef] 
88. Naranjo, M.; Forment, J.; Roldan, M.; Serrano, R.; Vicente, O. Overexpression of Arabidopsis thaliana LTL1, a salt-induced gene encod-ing a GDSL-motif lipase, increases salt tolerance in yeast and transgenic plants. Plant Cell Environ. 2006, 29, 1890-1900. [CrossRef]

89. Li, N.N.; Qian, W.J.; Wang, L.; Cao, H.L.; Hao, X.Y.; Yang, Y.J.; Wang, X.C. Isolation and expression features of hexose kinase genes under various abiotic stresses in the tea plant (Camellia sinensis). J. Plant Physiol. 2017, 209, 95-104. [CrossRef]

90. Van Gisbergen, P.A.; Bezanilla, M. Plant formins: Membrane anchors for actin polymerization. Trends Cell Biol. 2013, 23, 227-233. [CrossRef]

(C) 2019 by the authors. Licensee MDPI, Basel, Switzerland. This article is an open access article distributed under the terms and conditions of the Creative Commons Attribution (CC BY) license (http://creativecommons.org/licenses/by/4.0/). 